\title{
Ortaokul Cebirsel Faaliyetlerde Matematiksel Süreç Standartlarının Kullanım Durumu
}

\section{Elif KILIÇOĞLU*}

Öz: Bu çalışmada ortaokul matematik ders kitaplarının cebir öğrenme alanında yer alan faaliyetlerin matematiksel süreç standartları çerçevesinde incelenmesi amaçlanmıştır. Matematiksel süreç standartları problem çözme, problem kurma, muhakeme-ispat, iletişim, ilişkilendirme ve temsil olmak üzere altı başlık altında toplanmıştır. Araştırmanın çalışma grubunu, Milli Eğitim Bakanlığı'nın Hatay ili için kullanımını önerdiği ders kitaplarının cebir öğrenme alanında yer alan tüm matematiksel faaliyetler oluşturmaktadır. Ders kitaplarında yer alan hazırlık soruları, örnekler, problemler, etkinlikler, uygulama ve değerlendirme sorularının her biri birer faaliyet olarak belirlenmiş ve toplamda 396 tane faaliyet analiz edilmiştir. Çalışmada doküman incelemesi yöntemi kullanılmış olup, söz konusu faaliyetler betimsel analiz yöntemi ile analiz edilmiştir. 5. sınıfta cebir öğrenme alanına ait herhangi bir kazanım bulunmadığı için bu sınıfa ait veri elde edilememiştir. Elde edilen bulgulara göre, ortaokul cebirsel faaliyetlerin her sınıf seviyesinde de en fazla iletişim özelliğinde olduğu, en az ise problem kurma özelliğinde olduğu bulunmuştur. Özellikle 7. sınıf cebirsel faaliyetlerinin süreç standartları bakımından diğer sınıf düzeylerine nazaran daha iyi düzeyde olduğu fark edilmiştir. Sonuç olarak ortaokul ders kitaplarında yer alan cebirsel faaliyetlerin problem çözme, problem kurma, muhakeme-ispat ve temsil standartları bakımından yetersiz olduğu, sınıf düzeylerinin matematiksel süreç standartlarını yansıtan faaliyetleri bakımından farklılaştı̆ğ ve konu anlatımı sırası ve konu sonu faaliyetlerinin süreç standartları bakımından uyuşmadığı bulunmuştur.

Anahtar kelimeler: Matematiksel süreç standartları, Matematik müfredat1, Matematik öğretimi, Ders kitabı, Doküman analizi.

\section{Analysis of Secondary School Textbooks in the Context of Mathematical Process Standards}

Abstract: In this study, it is aimed to examine the activities in the algebra learning field of secondary school mathematics textbooks within the framework of mathematical process standards. Mathematical process standards are grouped under six headings as problem solving, problem posing, reasoning and proof, communication, connection and representation. In the research, all the mathematical activities in the algebra learning field of the textbooks proposed by the Ministry of National Education for the province of Hatay constituted the working group. Preparation questions, examples, problems, activities, application and evaluation questions in the textbooks are each determined as an activity. A total of 396 activities are analyzed. The document review method was used in the study, and these activities were analyzed according to descriptive analysis. Since there was no acquisition in algebra learning area in the 5th grade,

*Dr. Öğr. Üyesi, Hatay Mustafa Kemal Üniversitesi, Eğitim Fakültesi, Matematik ve Fen Bilimleri Eğitimi Bölümü, Email: elifacil@mku.edu.tr, Orcid No: 0000-0001-7904-4310.

\begin{tabular}{lll}
\hline Gönderim:28.07.2020 Kabul:17.09.2020 & Yayın:15.01.2021
\end{tabular}


data related to this class could not be obtained. According to the findings, $19.19 \%$ of 396 activities are problem solving, $0.50 \%$ problem-posing, $6.81 \%$ reasoning-proof, $49.74 \%$ communication, $32.57 \%$ connection and $16.91 \%$ representation. As a result, algebraic activities in secondary school textbooks are inadequate in terms of problem solving, problem-posing, reasoning-proof and representation standards, class levels differ in terms of activities reflecting mathematical process standards, activities differ in terms of process standards, and subject expression and end-of-process activities in terms of process standards found to be incompatible.

Key words: Mathematical process standards, Mathematical curriculum, Mathematics teaching, Textbook, Document analysis.

\section{Giriş}

Bir disiplin olarak matematik yapısındaki soyutluk nedeni ile genellikle zor ve karmaşık görülmüştür (Işık ve Konyalığlu, 2005). Matematiğin zorluğu çalışmalarda dile getirilmiş ve araştırmacılar bunun üstesinden gelmek için arayışlar içerisine girmişlerdir. $\mathrm{Bu}$ zorluğun nedenini araştıran araştırmacılar bazen matematiğin yapısal soyutluluğunu öne sürmüş (örn. Dursun ve Dede, 2004), bazen öğretmenlerin öğretim şeklini eleştirmiş (örn. Hare, 1999), bazen bu zorluğun öğrencilerin başarı durumu ile ilişkili olduğunu ifade etmiş (örn. Stein ve Lane, 1996), bazen de velilerin ve sosyal çevrenin tutumunun (örn. Papanastasiou, 2002) bu durumu etkilediğini ileri sürmüşlerdir. Sonuç olarak matematiğin zorluğunun sebebinin çeşitlilik gösterdiği ifade edilebilir. Sebebi ne olursa olsun, matematik gerçek hayatta başarılması gereken bir disiplin olarak yer almıştır. Ailelerin hemen hemen hepsi çocuklarının matematikte başarılı olmasından gurur duyar ya da başarılı olmasını ister. Bu durum sadece aileler için geçerli değildir. Bir öğretmen sınıfındaki, bir müdür okulundaki ya da bir bakan ülkesindeki öğrencilerin başarılı olmasını bekleyebilir. Bu bekleyişin araştırmalardaki arayışın temelini oluşturduğu söylenebilir.

Dünyanın bilim ve teknoloji anlamında ilerlemesi ile gelişmişlik düzeyine erişmek ülkelerin hedefinde yer almıştır. Her ülke kendi hedefini gerçekleştirmek için sosyal, kültürel, sağlık, siyasal, ekonomi ve eğitim gibi alanlardaki değişimi ve gelişimi takip etmektedir. Özel olarak eğitim alanındaki teknolojinin ilerlemesi ile zorunlu olan değişiklikleri dikkate almak, ülkelerin gelecek planlarının merkezi konumunda yer almaktadır. Nitekim eğitimin amacı hayat boyu öğrenen, üreten ve yeniliklere ayak uydurabilen birey yetiştirmektir (Olkun ve Toluk Uçar, 2012). Milli Eğitim Bakanlığı [MEB] (2018) ise eğitim sisteminin temel amacının, değerlerimizle bütünleşmiş bilgi, beceri ve davranışlara sahip bireyler yetiştirmek olduğunu ifade etmektedir. Bu bilgi, beceri ve davranışlar genel yetkinlikleri oluşturmakta ve bireylere eğitim sistemimizde yer alan programlar çerçevesinde kazandırılmaktadır.

Türkiye Yeterlilikler Çerçevesinde [TYÇ] belirlenen temel yetkinliklerden biri matematiksel yetkinliktir. Matematiksel yetkinlik, bireyin normal yaşamında karşılaştığ problemleri çözebilmesi için matematiksel düşünmesini geliştirmedir (TYÇ, 2018). Bu kavram ayrıca matematiksel düşünme ve uygulamanın kullanabilme becerisi ile ilişkilidir. Ulusal Matematik Öğretmenleri Konseyi'ne [NCTM] (2020) göre matematik alanındaki yeterlilik, üretken ve parlak geleceğin anahtarıdır ve bir takım becerilerden oluşmaktadır. Konsey bu becerileri, öğrencinin matematiği bilmesini ve yapmasını sağlayan süreç standartları olarak ifade etmiş ve problem çözme, muhakeme ve ispat, iletişim, ilişkilendirme ve temsil olmak 
üzere beş başlık altında toplamıştır. MEB (2018) matematik müfredatında ise bu süreç standartlarının önemi özel amaçlar başlığı altında madde madde açıklanmıştır. Müfredatta özetle, öğrencilerin düşünce ve akıl yürütmelerini rahatlıkla ifade edebilecekleri, matematiksel düşüncelerini açıklayabilmek için matematiksel dili kullanabilecekleri, matematiksel nesnelerin birbirleri ile olan ilişkilerini anlamlandırabilecekleri, matematiksel kavramları farklı şekillerde temsil edebilecekleri, tahmin etme ve zihinden işlem yapma becerilerini etkin bir şekilde kullanabilecekleri ve daha fazlası ifade edilmiştir. Müfredatta yer alan matematiksel kazanımlar incelendiğinde ve ayrıca matematiğin özel amaçları dikkate alındığında problem çözmeden ayrı olarak problem kurma becerisinin de yer aldığg fark edilmiştir (bkz. MEB, 2018). Dolayısıyla problem kurmanın problem çözmeden ayrı bir süreç standardı olarak ele alınmasının uygun olduğu düşünülmektedir. Standartların ne anlama geldiğine dair özet açıklamalar şu şekildedir:

\section{Problem çözme}

Problem çözme matematik eğitiminde özel bir öneme sahiptir. Wilson, Fernandez ve Hadaway'a (1993) göre matematik öğretimi ve öğreniminde temel amaç, bireyin çeşitli ve karmaşık matematiksel problemleri çözme becerilerinin geliştirilmesidir. Problem çözme, matematiksel problemin sonucunu bulmaktan daha fazlasıdır. Marshall'a (1996) göre problem çözme, yeni durumlarla karşılaşmak ve bu durumlarla başa çıkmak için faydalı çözümler sunmaktır. Polya (2004) ise problem çözmenin bir zorluktan kurtulma çabası olduğunu ileri sürmüş ve bu çabanın hemen sonuçlanma isteğinin problem çözme sürecinin esas durumu olduğunu ifade etmiştir. Polya’ya (2004) göre problem çözme süreci sistematik bir süreçtir ve öğreticinin bu süreci kolaylaştırması önemli ve gereklidir. Bunu sağlamak için sürecin parçalara ayrılmasını önermektedir. Problem çözme sürecini problemin anlaşılması, çözümün planlanması, planın uygulanması ve kontrol olmak üzere dört aşamada tanımlamak gerektiğini ifade etmektedir.

\section{Problem kurma}

NCTM (2020) raporunda öğrencilerin karmaşık matematiksel durumları formüle etmelerinden bahsedilmektedir, fakat problem kurma kavramsal olarak raporda yer almamaktadır. Nitekim raporda sadece problem çözme bir süreç standardı olarak ifade edilmiştir. Ellerton ve Clarkson (1996) matematik eğitiminin problem kurma ve çözme olmak üzere iki temele dayandığını söylemektedir. Silver'e (1994) göre problem kurma, öğrencilerin önceden formüle edilmiş problemleri çözmelerinin yanı sıra kendi problemlerini üretebildikleri faaliyetlerdir. Yani problem kurma faaliyeti hem verilen problemi yeniden formüle etmek hem de yeni bir problem üretmek için yapılabilir. Böylelikle problem kurma, problemin çözümü öncesinde, sırasında ya da sonrasında ortaya çıkabilir (Silver, 1994). Matematiğin ilerlemesi yaratıcılı gerektirir ve problem kurma buna aracılık eden önemli bir faaliyettir (Christou, Mousoulides, Pittalis, Pitta-Pantazi ve Sriraman, 2005). Dolayısıyla problem kurmanın öğrencilerin yaratıcılığının geliştirilmesi için önemli bir araç olduğu ifade edilebilir.

\section{Muhakeme ve İspat}

Dayanak oluşturarak matematiksel ifadelerden emin olmak için yapılan bir sonuç çıkarma işlemidir. Knuth'a (2002) göre ispat matematik öğretimi için oldukça önemli bir araçtır ve matematiksel anlamayı destekleyerek öğrenci öğrenmesine fayda sağlar. Stylianides (2008) tarafindan muhakeme ve ispat, matematiksel genellemeler yapma ve matematiksel iddialara 
kanıt sağlama olmak üzere iki kısımda ele alınmıştır. Araştırmacı ilk kısmı örüntü bulma ve çıkarım yapma; ikinci kısmı ise ispat sağlama ve ispat olmayan argüman sağlama olarak açıklamaktadır. Diğer yandan matematiksel ispat ile ilgilenen Almeida’ya (2000) göre matematiksel ispat, matematiksel bilgi için garanti sağlar ve matematiksel anlayışın gelişimi için temel bir aktivite özelliğindedir. Benzer şekilde Hanna ve Barbeau (2008) ise matematiksel ispatın, matematiksel bilgilerin ilişkilendirilerek stratejik olarak sonuçlandırılmasına dayanan bir araç olduğunu ifade etmektedirler. Dolayısıyla ispatın, matematiğin sistematik gelişimine katk1 sağlayacak bir standart olduğu söylenebilir.

\section{İletişim}

Matematiksel iletişim, matematiksel fikirleri paylaşmanın bir yoludur (NCTM, 2020). Matematiksel düşüncelerin sözlü ve yazılı olarak ifade edilmesinde kullanılan her şey iletişim kapsamına girmekte ve bu yapı matematiksel dil olarak adlandırılmaktadır. Uğurel ve Moralı (2010) matematiğin kendine özel simgesel, sembolik ve sözcüksel yapısı ile sistematik ve uluslararası bir dile sahip olduğunu ifade etmektedirler. Ferrari (2004) dilin matematik öğretiminde kritik bir öneme sahip olduğunu söylemektedir. Cooke ve Buchholz’a (2005) göre küçük çocukların matematikte kendini ifade edebilmesi için matematiksel dili kullanmaları gerekmektedir. Küçük çocukların matematiksel düşüncelerinin netleştirilmesi ve matematiksel anlayışlarının kesinleştirilmesi için öğretmenleri ile etkileşimleri önemli görülmektedir (Kennedy, Tipps ve Johnson, 2004). Böylelikle matematik ile dil arasında bir bağlantı kurulmalıdır. Brendefur ve Frykholm'a (2000) göre matematiksel başarının merkezinde, öğrencilerin zengin matematiksel bilginin geliştirilmesinde akranları ve öğretmenlerle etkileşime girmesini sağlayan yazılı ve sözlü iletişim biçimleri yer almaktadır.

\section{İlişkilendirme}

NCTM (2020) matematiğin konularının bağımsız olmadığını, aksine entegre bir çalışma alanı olduğunu söylemektedirler. Ayrıca öğrencilerin matematiksel fikirlerin birbiriyle ilişkisini temele alan bir öğretime maruz kalmaları durumunda sadece matematiği değil, matematiğin ne kadar işe yarar olduğunu da öğreneceklerini ifade ederler. Yulianto, Rochmad ve Dwidayati' ye (2019) göre ilişkilendirme çeşitli matematiksel kavramlar arasında bağlantı kurmaya yarayan bir beceridir. Putri ve Santosa (2015) da bu beceriyi, matematiksel kavramlar ile öğrenenin günlük yaşamı ya da diğer matematiksel kavramlar arasında bağlantı kurabilme becerisi olarak ifade etmektedirler. Matematiğin bunların dışında diğer bilimlerle ilişkisi de yüksek düzeydedir. Çünkü matematik diğer bilimlerin temelinde yer alır ve böylelikle diğer bilimlerin matematiğe bağımlılı̆̆ından bahsedilebilir.

\section{Temsil}

Bir matematiksel ifade sayı, şekil, somut materyal gibi farklı şekillerde ifade edilebilir. Matematiksel ifadenin nasıl temsil edileceğinin seçimi öğrenenin yorumlama yeteneği ile ilişkilidir (NCTM, 2020). Yani model olarak gösterilen fikirlerin birey zihninin ürünü olan matematiksel ifadesidir. Temsil, gerçekçi soruların cevaplanması için ilk adımdır (Abrams, 2007). Pape ve Tchoshanov (2001) matematiksel temsili, (1) öğrencilerin deneyimleriyle gelişen matematiksel fikirlerin veya bilişsel şemaların bir iç soyutlaması, (2) ilk zihinsel durumun yeniden inşası, (3) resimler, semboller ve işaretler yardımı ile yapısal olarak eş bir gösterim ve (4) bir şeyin yerine başka bir şey, olmak üzere dört açıdan tanımlamışlardır. Diğer 
yandan Cuoco’ya (2001) ve Goldin'e (2003) göre matematiksel temsil, matematiksel fikirleri açıklayan ya da temsil eden karakterler, işaretler, simgeler ya da nesnelerin yapılandırılmasıdır.

Süreç standartlarının açıklamalarından hareketle anlaşılırlığını kolaylaştırmak için standartları özetleyen kavramlar Tablo 1'de verilmiştir:

Tablo 1. Süreç standartları ile ilgili çerçeve

\begin{tabular}{ll}
\hline Süreç Standartları & Açıklamaları \\
\hline Problem Çözme & Merak etme, sonuca ulaşma, sistematik ilerleme \\
\hline Problem Kurma & Yeniden formüle etme, problem üretme, problem oluşturma \\
\hline Muhakeme ve İspat & $\begin{array}{l}\text { Genelleme yapma, kanıt sağlama, doğruluğunu gösterme, emin } \\
\text { olma }\end{array}$ \\
\hline İletişim & Matematiksel dil, sembol, şekil, notasyon kullanma \\
\hline İlişkilendirme & Bağlantı kurma, günlük hayat \\
\hline Temsil & Farklı gösterim, materyal, model \\
\hline
\end{tabular}

Bu çalışmada ortaokul matematik ders kitaplarının cebir öğrenme alanında yer alan faaliyetlerin Tablo 1'de yer alan matematiksel süreç standartları çerçevesinde incelenmesi amaçlanmıştır. Bu çalışmanın önemi üç başlık altında ifade edilebilir. İlki matematiksel süreç standartlarının tamamının bu çalışma dâhilinde olmasıdır. Literatürde yer alan benzer çalışmalar, araştırmacıların ders kitaplarındaki etkinliklerin incelenmesinde genellikle bir ya da iki beceriye odaklandıklarını göstermektedir (bkz. Çimen ve Yıldız, 2017; Zeybek Üstün ve Birol, 2018). Böylelikle kapsamı genişletilmiş bu çalışma ile daha geniş kitleye hitap edileceği düşünülmektedir. Matematiksel becerilerin bireye kazandırılması, hedeflenen amaçları gerçekleştirmek için atılan önemli bir adımdır. Alan yazında becerilerin matematik öğretimi ve öğrenimi sürecindeki olumlu etkilerinden bahseden pek çok çalışma yer almaktadır (örn. Ramirez, Chang, Maloney, Levine ve Beilock, 2016; Stylianides, 2007). Sukmaningthias ve Hadi'ye (2016) göre matematiksel düşünme becerileri, bir problemi çözmede ve özellikle yüksek dereceli düşünme becerilerinde matematik öğrenme hedeflerine ulaşmada bir ölçüttür. İkinci olarak bu çalışmada ders kitaplarının matematiksel süreç standartları çerçevesinde analizinin yapılması değerli görülmektedir. Ders kitapları öğrencilerin ilgili ders için karşılaştığı ilk dokumandır. Bu özelliği ile ders kitaplarının öğretim sürecinin önemli bir parçası olduğu ifade edilebilir. Ders kitaplarında yer alan faaliyetlerin becerileri ne kadar temsil ettikleri açısından incelenmesi matematiksel öğrenme için önemlidir. Bu tarz çalışmalar ders kitaplarının gelişim sürecine 1 şı tutabilir ve ne yapılması ya da ne yapılmaması gerektiği hususunda fikir verebilir. Johansson'a (2003) göre ders kitabı inceleme çalışmaları ülkelerin eğitim reformu çalışmalarına destek sağlayabilir. Ayrıca araştırmacı ders kitaplarının öğrencilere ve öğretmenlere matematiğin anlaşılması hususunda çeşitli avantajlar sağladığını da ifade etmektedir. Diğer yandan Smith III, Males, Dietiker, Lee ve Mosier'a (2013) göre ders kitabındaki sınırlılıkların ortaya koyulması, öğrencinin öğrenme firsatlarını sınırlayan durumları azaltabilir ya da öğrenmede zorlandığı noktaların belirlenmesinde ve giderilmesinde yardımcı olabilir. Son olarak çalışmada özel olarak cebir öğrenme alanının seçilmesi de değerli görülmüştür. Cebir, bireyin erken çocukluktan itibaren gördüğ̈ ve öğretim hayatı boyunca karşılaştığı bir öğrenme alanıdır (Bush ve Karp, 2013). Trybulski (2007) cebirsel düşünmenin cebirin belirleyicisi olduğunu ifade ederken, yalnızca cebir çalışmalarıyla ilgili olmadığını, 
problem çözme, akıl yürütme, temsil gibi matematiksel düşünmenin kullandığı süreç becerilerini de içerdiğini söylemektedir. $\mathrm{Bu}$ açıdan cebirsel düşünmenin matematiksel düşünmenin bir formu olduğu öne sürülebilir. Dolayısıyla bu öğrenme alanının matematiksel becerileri temsil etme gücünün ortaya çıkarılması önemli görülmektedir. Araştırma da temelde şu problem durumuna cevap aranmaya çalışılmıştır:

- Ortaokul matematik ders kitaplarının cebirsel faaliyetlerinde matematiksel süreç standartlarının yer alma durumunu nedir?

\section{Yöntem}

\section{Araştırmanın Deseni}

$\mathrm{Bu}$ çalışmada ortaokul matematik ders kitaplarında yer alan cebirsel faaliyetler incelenmiştir. $\mathrm{Bu}$ yönüyle araştırma bir tür dokuman incelemesidir. Dokuman incelemesi katılımcı ile araştırmacının karşı karşıya gelmediği etkileşimsiz nitel veri toplama yöntemidir (Mcmillan ve Schumacher, 2010, s. 360). Araştırmanın dokümanları, cebirsel faaliyet olarak adlandırılan, hazırlık soruları, örnek, problem, etkinlik, uygulama ve değerlendirme sorularıdır.

\section{Çalışma Grubu}

Bu araştırmanın çalışma grubu, Hatay ili bölgesinde MEB tarafından 2018-2019 eğitimöğretim yılında ortaokulun tüm sınıf düzeylerinde kullanımı önerilerin matematik ders kitaplarında cebir öğrenme alanında yer alan faaliyetlerin hepsidir. Cebir, bireyin erken yaşlarda karşılaştığı bir öğrenme alanı olmasına rağmen, müfredatta ilk olarak 6. sınıfta yer aldığı görülmektedir. İncelenen kitaplar 5. sınıf için SDR Dikey; 6. sınıf için Berkay; 7. sınıf için Koza; 8. sınıf için Ekoyay Yayınları'nın 2018 yılında beş yıl süre ile MEB kurumlarınca kullanımı uygun bulunan kitaplardır. Araştırmada kullanılan faaliyet kavramı ile cebir öğrenme alanındaki etkinlik, hazırlık soruları, örnekler, problemler, alıştırma soruları, ölçme soruları ve değerlendirme sorularının tamamı kastedilmektedir. Kitaplarda yer alan ölçme soruları, alıştırma soruları, uygulama soruları bulgular kısmında anlaşılırlığının sağlanması bakımından uygulama soruları başlığı altında verilmiştir. Ünite sonu değerlendirme soruları ise değerlendirme soruları başlığı altında verilmiştir.

Ortaokul 5. sınıfta cebir öğrenme alanı ile ilgili herhangi bir kazanım yer almadığı için bu sınıfa ait veri elde edilememiştir. 6. sınıfta cebirsel ifadeler alt öğrenme alanına ait toplam 25; 7. sınıfta cebirsel ifadeler ve eşitlik ve denklem alt öğrenme alanlarına ait toplam 104; 8 . sınıfta cebirsel ifadeler ve özdeşlikler, doğrusal denklem ve eşitsizlikler alt öğrenme alanlarına ait toplam 267 faaliyet incelenmiştir. Yani ortaokul matematik programının cebir ögrenme alanına ait toplam 396 faaliyet bu araştırmanın çalışma grubunu oluşturmaktadır. Bu verilere ait bilgiler Ek 1'de yer almaktadir.

\section{Veri Toplama Aracı ve Süreci}

Araştırmada veri toplamak için öncelikle ders kitaplarında yer alan faaliyetlerin hepsi betimsel olarak tespit edilmiş ve her sınıf düzeyi için bu betimsel verilere ait tablolar oluşturulmuştur. Diğer yandan matematiksel süreç standartları ile matematiksel faaliyetleri eşleştiren veri toplama aracı tablosu oluşturulmuştur (Tablo 2).

Tablo 2. Veri toplama arac1

\begin{tabular}{llllll}
\hline Baaliyet & $\begin{array}{l}\text { Problem } \\
\text { Çözme }\end{array}$ & $\begin{array}{l}\text { Problem } \\
\text { Kurma }\end{array}$ & $\begin{array}{l}\text { Muhakeme- } \\
\text { İspat }\end{array}$ & İletişim İlişkilendirme & Temsil \\
\hline
\end{tabular}




\begin{tabular}{l}
\hline Hazırlık Sorusu 15 \\
\hline Etkinlik \\
\hline Örnek \\
\hline Problem \\
\hline Uygulama Soruları \\
\hline Değerlendirme Soruları \\
\hline Toplam \\
\hline
\end{tabular}

Tablo 2'de her bir hücre faaliyetler ile standartların kesişimini yansıtmaktadır. Örneğin ilk hücrede yer alan 15 sayısı ilgili sınıf düzeyinde cebir öğrenme alanına ait 15 hazırlık sorusunun problem çözme becerisini yansıttığını göstermektedir. Benzer şekilde yine Tablo 2'de yer alan 43 sayısı ile, ait olduğu sınıf düzeyindeki 43 örneğin ilişkilendirme becerisi özelliğinde olduğu kastedilmektedir.

\section{Veri Analizi}

$\mathrm{Bu}$ araştırmanın verileri betimsel analiz yöntemleri kullanılarak analiz edilmiştir. Betimsel analiz, verilerin daha önceden belirlenen kategorilere göre özetlenmesi ve yorumlanmasıdır (Yıldırım ve Şimşek, 2011, s. 224). Öncelikle her bir faaliyetin sayısı belirlenmiş ve genel bir değerlendirme yapılmıştır. Ardından faaliyetlerin sınıf düzeyine göre ayrıntılı analizleri yapılmıştır. Matematiksel faaliyetlerin analizi matematiksel standartlara ait analitik çerçeveye göre yapılmıştır. $\mathrm{Bu}$ analitik çerçeve her bir matematiksel standardı tanımlayan anahtar kelimelerden oluşmaktadır (Tablo 1). Örneğin 7. sınıfa ait bir etkinlik şu şekilde analiz edilmiştir:

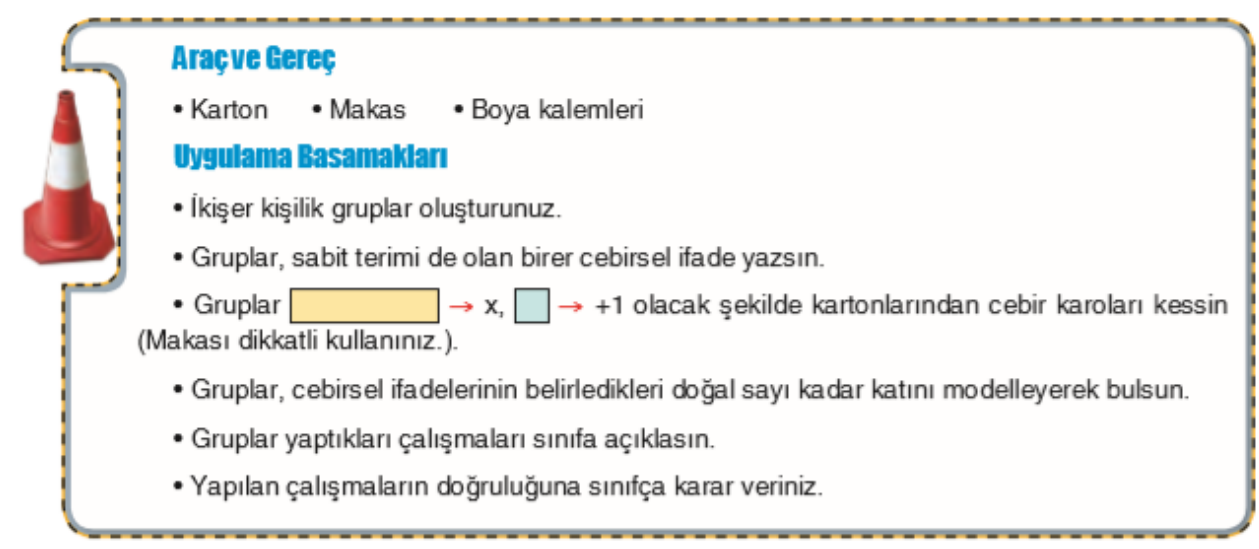

Şekil 1. 7. sınıf faaliyeti (Koza, 2018, s. 107)

Şekil 1'de yer alan etkinlik öncelikle kodlanmıştır. Bu etkinlikten elde edilen kodlar, cebirsel ifade yazmak, modelleme yapmak, açıklamak ve doğruluğunu göstermektir. Öğrencilerin cebirsel ifadeyi oluşturmaları matematiksel dili kullanabilmeleri ile, modelleme yapmaları bir ifadeyi farklı temsiller aracılığıyla gösterme ile, doğruluğunu gösterme ise muhakeme yapma ile ilişkilendirilmiştir. Sonuç olarak bu etkinlik iletişim, temsil ve muhakemeispat standartları altında değerlendirilmiştir.

Verilerin analizlerinin güvenirliği, özellikle herhangi bir uygulamanın yapılmadığı dokuman incelemesi yöntemlerinde daha önemli bir hal almaktadır. Bu çalışma için öncelikle betimsel analizin kontrollü şekilde yürütülmesi amacıyla başka bir araştırmacı tarafından betimsel verilerin kontrolü sağlanmıştır. Ardından başka bir araştırmacı tarafından verilerin analizi yapılarak araştırmacının analizinin güvenirliği ölçülmüştür. Yapılan analizler 
karşılaştırılmış ve kodlayıcı uyumu yaklaşı \% 092 olarak hesaplanmıştır. Uyum katsayısı Miles ve Huberman (1994) tarafından önerilen, Güvenirlik Yüzdesi = ((Görüş Birliği)/( Görüş Birliği+Görüş Ayrılığı))x100 formülü ile hesaplanmıştır. Uyumsuzluk yaşanan faaliyetlerin sonucu bir arada tartışılarak karara bağlanmıştır. Örneğin Şekil 2'de kodlayıcılar arasında uyumsuzluk yaşanan 8. sınıfa ait bir faaliyet verilmiştir.

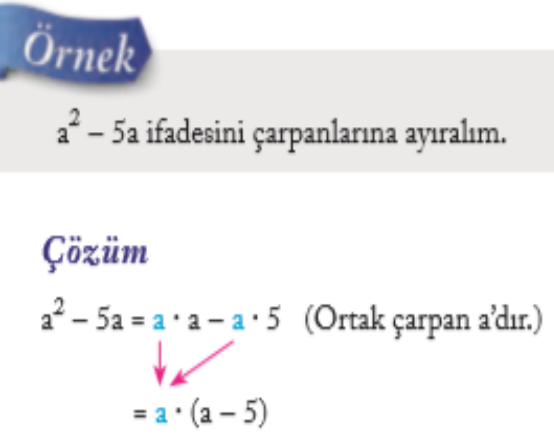

Şekil 2. 8. sınıf faaliyeti (Ekoyay, 2018, s. 125)

Şekil 2'de yer alan faaliyet için ilk kodlayıcı ilişkilendirme; ikinci kodlayıcı hem ilişkilendirme hem de iletişim kodunu kullanmıştır. Bir araya geldikten sonra kodlayıcılar faaliyette yer alan iki terimin ortak çarpanlarının bulunmasının ilişkilendirme ile ilgili olduğu konusunda hem fikir olmuşlardır. Ayrıca bu cebirsel ifadenin ortak çarpan parantezine alınarak yazılmasının ise iletişim standardı altında değerlendirmesi gerektiğine karar verilmiştir.

Kodlayıcılar arasındaki diğer bir uyumsuzluk ise problem çözme standardı ile ilgili olmuştur. Birinci kodlayıcı her denklem çözme sorusunu problem çözme olarak kabul ederken, ikinci kodlayıcı bu soruların problem çözme olarak değerlendirilmemesi gerektiğini iddia etmiştir. Denklemin doğrudan faaliyette verilmesi ve bilinmeyenin bulunmasının istenmesi gibi görevleri barındıran faaliyetlerin problem çözme basamaklarını ihtiva etmediği için bu kategoride değerlendirilmemesi gerektiği kararlaştırılmıştır. Ayrıca verilerin analizinde bazı faaliyetlerin hiçbir standardı temsil etmediği fark edilmiştir. Örneğin; örüntünün kuralının verildiği ve belirli bir sıradaki sayının değerinin sorulduğu faaliyetlerin hiçbir matematiksel standardını yansıtmadığına dair karar verilmiştir.

\section{Etik Kurul Kararı}

Veri toplama süreci her bir sınıf düzeyi için ayrı ayrı olmak üzere, bilimsel araştırma ve yayın etiğine aykırı eylemlerden uzak bir şekilde gerçekleştirilmiştir.

\section{Bulgular}

$\mathrm{Bu}$ kısımda cebir öğrenme alandaki faaliyetler matematiksel süreç standartları çerçevesinde analiz edilmiştir. Elde edilen analizler öncelikle genel olarak değerlendirilmiş, ardından her bir sınıf için gerçekleştirilen analizler örnek durumları ile birlikte sunulmuştur.

\section{Genel Değerlendirme Bulguları}

Ders kitaplarında cebir öğrenme alanı ile ilgili toplamda 396 faaliyet tespit edilmiştir. $\mathrm{Bu}$ faaliyetler arasından ders kitaplarında örnek faaliyetin $(\mathrm{n}=151)$ en fazla yer aldığ 1 , hazırlık türü faaliyetlerinde $(n=6)$ en az yer aldığı görülmüştür. Ayrıca etkinlik sayısının da $(n=11)$ diğerlerine nazaran daha az olduğu tespit edilmiştir (bkz. Ek 1).

Faaliyetlere göre inceleme yapılacak olursa, cebir öğrenme alanı için 6 . sınıfta etkinliğe yer verilmediği, 7. sinıfta 6 tane ve 8. sınıfta 5 tane etkinliğin yer aldığ tespit edilmiştir. 
Cebirsel konuların hazırlık çalışmalarına ise 7. sınıfta yer verilmediği, 6. sınıfta $(n=5)$ ve 8 . sınıfta $(n=1)$ yer verildiği görülmüştür. Diğer yandan örnek türü faaliyetlere her sınıfta ve her alt öğrenme alanlarında yer verildiği fark edilmiştir. Benzer durum uygulama ve değerlendirme sorularında da vardır. Her iki faaliyette tüm sınıf düzeylerinde yer almıştır. Son olarak problem çözme faaliyetlerinin 6. sınıfta olmadığı, 7. ve 8. sinıflarda, özellikle 7. sınıfta $(n=16) 8$. sinıfa $(n=3)$ nazaran daha fazla yer verildiği saptanmıştır (bkz. Ek 1). Her sınıfa ait süreç standartlarının faaliyetlerde ne oranda temsil edildiğine dair veriler Tablo 3 'te verilmiştir.

Tablo 3. Genel Değerlendirme

\begin{tabular}{|c|c|c|c|c|c|c|}
\hline Sinıf Düzeyi & $\begin{array}{l}\text { Problem } \\
\text { Çözme }\end{array}$ & $\begin{array}{l}\text { Problem } \\
\text { Kurma }\end{array}$ & $\begin{array}{l}\text { Muhakeme- } \\
\text { İspat }\end{array}$ & İletişim & İlişkilendirme & Temsil \\
\hline 5. Sinıf & - & - & - & - & - & - \\
\hline 6. Sinıf & $1(\% 4)^{*}$ & $1(\% 4)$ & $1(\% 4)$ & $14(\% 56)$ & $2(\% 8)$ & $1(\% 4)$ \\
\hline 7. Sinıf & 33(\%31.73)* & $1(\% 0.96)$ & $24(\% 23.07)$ & $57(\% 54.80)$ & $16(\% 15.38)$ & $26(\% 25)$ \\
\hline 8. Sinıf & $42(\% 15.73)^{*}$ & - & $2(\% 0.74)$ & $126(\% 47.19)$ & $111(\% 41.57)$ & $40(\% 14.98)$ \\
\hline Toplam & 76(\%19.19)** & $2(\% 0.50)$ & $27(\% 6.81)$ & 197(\%49.74) & 129(\%32.57) & 67(\%16.91) \\
\hline
\end{tabular}

*Her sınıfın kendi faaliyet sayısı dikkate alınarak hesaplanmıştır.

**396 faaliyet sayısına göre hesaplanmıştır.

Matematiksel süreç standartları bakımından değerlendirilecek olursa, 396 faaliyetin \%19.19’u problem çözme, \%0.50'si problem kurma, \%6.81’i muhakeme-ispat, \%49.74’ü iletişim, \%32.57'si ilişkilendirme ve \%16.91'i temsil özelliğindedir (Tablo 3). Bu verilerle cebir öğrenme alanı faaliyetlerinin neredeyse yarısının iletişim özelliğinde olduğu ifade edilebilir. Sınıf seviyelerine göre incelendiğinde ise, her sınıf düzeyi için faaliyetlerde yine iletişim özelliğinin daha yaygın yer aldığı görülmektedir. Öğrencilerin soyutlama becerilerinin yaşa bağlı olarak giderek geliştiği düşüncesinden hareketle, süreç standartları bakımından faaliyetlerin de zenginleşmesi beklenmektedir. Fakat Tablo 3'te yer alan veriler bu durumu desteklememektedir. Problem çözme, iletişim, ilişkilendirme ve temsil standardı için her ne kadar faaliyet sayıları yıla göre artış gösterse de, o sınıf düzeyindeki cebirsel faaliyet sayısına göre değerlendirildiğinde herhangi bir artışın olmadığı anlaşılmaktadır. Örneğin, temsil standardı için 6 . sınıfta 1,7 . sınıfta 26 ve 8 . sınıfta 40 faaliyet tespit edilmiş ve faaliyet sayısı yıla göre artan sayıda ilerlemiştir. Fakat ait oldukları sınıf düzeyinde yer alan faaliyet sayılarına göre incelendiğinde 6 . sinıfta $\% 4,7$. sinıfta $\% 25$ ve 8 . sinıfta $\% 14.98$ oranında temsil özelliğinde faaliyet yer aldığı ve aslında düzenli bir artış olmadığı görülmektedir.

Problem çözme özelliği taşıyan 76 faaliyetin 68'inde iletişim özelliğinin de olduğu fark edilmiş, sadece 4'ünde sonucun doğruluğunun kontrol edilmesine dair işlem istenmiştir. Şekil 3 'te bir problem çözme faaliyeti yer almaktadır. 


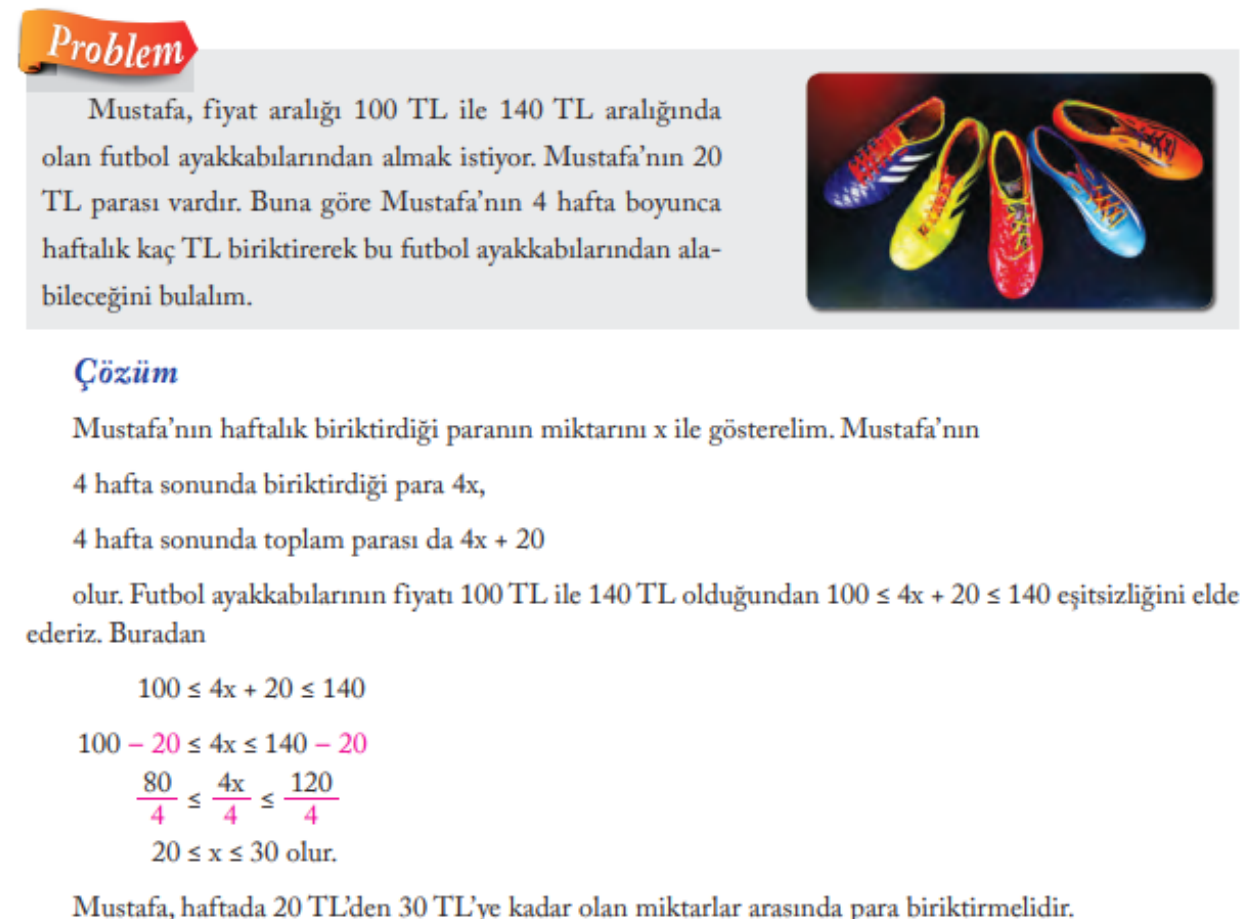

Şekil 3. 8. sınıf problem çözme faaliyeti (Ekoyay, 2018, s. 195)

Şekil 3'te yer alan faaliyet sistematik olarak belirli adımlarla ilerleyerek çözümün bulunduğu problem çözme özelliğinde bir faaliyettir. Mustafa'nın 4 hafta sonunda biriktirdiği para ifadesinin 4x olarak yazılması, sözel bir ifadenin matematik dille ifade edilmesi olarak açıklanabilir. Mustafa'nın toplam parasının ifade edilmesi, ayakkabıya verebileceği fiyatın sınırlarının matematiksel eşitsizlik olarak ifade edilmesi ve matematiksel işlemler sonrasında elde edilen eşitsizliğin yorumlanması, problemin matematiksel iletişim özelliğini taşıdığını göstermektedir. Ders kitaplarında yer alan cebirsel problem faaliyetlerinin genelinde bu yap1 vardır, ancak bazılarında sonucun doğruluğundan nasıl emin olacağı sorulmuş, bazılarında ise elde edilen sonuçların problem içindeki diğer matematiksel kavramlarla ilişkilendirilmesi ya da günlük hayatla ilişkilendirilmesi istenmiştir.

Son olarak sınıflar süreç standartlarına göre ele alınacak olursa, problem çözme, iletişim, ilişkilendirme ve temsil faaliyetlerinin 8. sınıfta, muhakeme-ispat faaliyetlerinin 7. sinıfta nispeten daha fazla olduğu ifade edilebilir (Tablo 3). Problem kurma faaliyetleri ile, ortaokul cebir etkinliklerinin tümü içerisinde, biri hazırlık sorusu (6. sınıf) biri etkinlik (7. sınıf) olmak üzere sadece iki kez karşılaşılmıştır. Diğer yandan muhakeme-ispat çalışmalarının ise daha çok etkinlik türü faaliyetlerde olduğu fark edilmiştir (bkz. Tablo 5-6).

\section{Sinıf Bulguları}

Bu sınıf düzeyinde müfredatta cebir öğrenme alanı ile ilgili kazanım yer almadığı için veri toplanamamıştır. Dolayısıyla herhangi bir analiz yapılamamıştır.

\section{Sinıf Bulguları}

6. sinifta saptanan 25 faaliyetin 5'i hazırlık sorusu, 6'sı örnek, 7'si uygulama sorusu ve 7 tanesi de değerlendirme sorusudur (bkz. Ek 1). Tablo 4'te 6. sınıfa ait cebirsel faaliyetlerin matematiksel süreç standartlarına göre analizi verilmiştir.

Tablo 4. 6. sinifa ait veri analizleri 


\begin{tabular}{|c|c|c|c|c|c|c|}
\hline Faaliyet & $\begin{array}{l}\text { Problem } \\
\text { Çözme }\end{array}$ & $\begin{array}{l}\text { Problem } \\
\text { Kurma }\end{array}$ & $\begin{array}{l}\text { Muhakeme- } \\
\text { İspat }\end{array}$ & İletişim & İlişkilendirme & Temsil \\
\hline Hazırlık Soruları & 1 & 1 & 1 & - & - & - \\
\hline Örnek & - & - & - & 5 & - & 1 \\
\hline Uygulama Soruları & - & - & - & 4 & 1 & - \\
\hline Değerlendirme Soruları & - & - & - & 5 & 1 & - \\
\hline Toplam & $1(\% 4)^{*}$ & $1(\% 4)$ & $1(\% 4)$ & $14(\% 56)$ & $2(\% 8)$ & $1(\% 4)$ \\
\hline
\end{tabular}

*25 faaliyet içindeki oranı temsil etmektedir.

6. sınıf için incelenen faaliyetlerin bazılarında temel matematiksel işlemlerin sorgulandığı ve dolayısıyla matematiksel becerilerin herhangi birinin özelliğini taşımadığ tespit edilmiştir. Örneğin, " $m-2$ cebirsel ifadesinin değerini $m=6$ için bulunuz." gibi sorular herhangi bir beceri tarafından kodlanamamıştır (bkz. Berkay, 2018, s. 201). Aksine birden fazla beceriyi yansıtan faaliyetler de saptanmıştır. Şekil 4'te yer alan hazırlık sorusu bu durumu örneklemektedir:

2. C̣özümünde yanda verilen ișlemlerin kullanılabileceği iki farklı problem kurunuz. Problemleri çözerek doğruluğunu kontrol ediniz.

$$
\begin{aligned}
40+50 & =90 \\
4.90 & =360
\end{aligned}
$$

Şekil 4. 6. sınıf hazırlık sorusu (Berkay, 2018, s. 195)

Şekil 4'te yer alan etkinlikte iki işlem verilmiş ve öğrencilerden bu işlemleri içeren iki farklı problemin kurulması istenmiştir. Ardından öğrencilerden problemleri çözerek, elde ettikleri sonucun doğruluğunu kontrol etmeleri istenmiştir. Bu etkinlik araştırmacı tarafından problem oluşturma ve doğruluğun kontrol edilmesi olarak kodlanmış ve matematiksel süreç standartlarından problem kurma ve muhakeme-ispat standard 1 çerçevesinde değerlendirilmiştir. Çözüme dair işlem verildiği ve sistematik ilerlemeye dair herhangi bir yönlendirme olmadığ için problem çözme standardı altında değerlendirilmemiştir.

Tablo 4 incelendiğinde faaliyetlerin \%56'sının iletişim standardı özelliğinde olduğu tespit edilmiştir. $\mathrm{Bu}$ oran diğer standartlarla kıyaslandığında en fazla olandır. Diğer standartların ise bir ya da iki faaliyetle temsil edildiği fark edilmiştir. İlişsilendirme olarak kodlanan faaliyetlerin ikisinde de verilen ifadenin günlük hayatla ilişkilendirilmesi istenmiştir. Faaliyetlerde genel olarak öğrencilerden "verilen bir sözel ifadenin matematik cümlesinin yazılması" ya da "cebirsel ifadenin sözel olarak ne anlama geldiğinin örneklerle açıklanması", istenmiştir. $\mathrm{Bu}$ gibi durumları içeren faaliyetler matematiksel dil becerisi ile ilişkili olup, iletişim standardı özelliği taşımaktadır.

Son olarak 6. sınıf için veri analizi sırasında dikkat çeken diğer bir durum ise, öğrencilerin bilgilerinin ölçüldüğü uygulama ve değerlendirme sorularında da genel değerlendirmede olduğu gibi çoğunlukla iletişim özelliğinde olmasıdır. Benzer şekilde, konu anlatımının yapıldı̆̆ı örnek türü faaliyetlerde de iletişim özelliğinin baskın olduğu fark edilmiştir.

\section{Sinıf Bulguları}

7. sınıfta cebir öğrenme alanı ile ilgili toplam 104 faaliyet tespit edilmiştir. Faaliyetlerin 6'sının etkinlik, 34'ünün örnek, 16'sının problem, 14'ünün uygulama sorusu ve 13'ünün 
değerlendirme sorusu olduğu görülmektedir (bkz. Ek 1). Bu faaliyetlerin matematiksel süreç standartlarına göre analizi Tablo 5'te yer almaktadır.

Tablo 5. 7. sinifa ait veri analizleri

\begin{tabular}{|c|c|c|c|c|c|c|}
\hline Faaliyet & $\begin{array}{l}\text { Problem } \\
\text { Çözme }\end{array}$ & $\begin{array}{l}\text { Problem } \\
\text { Kurma }\end{array}$ & $\begin{array}{l}\text { Muhakeme- } \\
\text { İspat }\end{array}$ & İletişim & İlişkilendirme & Temsil \\
\hline Etkinlik & 1 & 1 & 5 & 3 & 2 & 3 \\
\hline Örnek & 7 & - & 13 & 17 & 11 & 12 \\
\hline Problem & 16 & - & 3 & 16 & - & - \\
\hline Uygulama Soruları & 6 & - & 3 & 15 & 1 & 8 \\
\hline $\begin{array}{l}\text { Değerlendirme } \\
\text { Soruları }\end{array}$ & 3 & - & - & 6 & 2 & 3 \\
\hline Toplam & 33(\%31.73)* & $1(\% 0.96)$ & $24(\% 23.07)$ & $57(\% 54.80)$ & $16(\% 15.38)$ & $26(\% 25)$ \\
\hline
\end{tabular}

*104 faaliyet içindeki oranı temsil etmektedir.

Tablo 5 'te görüldüğ̈̈ gibi faaliyetlerin diğer standartlara nazaran \%54.80 oranla en fazla iletişim ve \%0.96 oranla en az problem kurma özelliğinde olduğu tespit edilmiştir. Faaliyetlerde ilişkilendirme standardının da diğerlerine nazaran daha az yer aldığı dikkat çekmektedir. Diğer yandan faaliyet türlerinin özellikleri incelendiğinde her birinin en az üç standartla temsil edildiği görülmektedir. Örneğin, değerlendirme sorularında problem çözme, iletişim, ilişkilendirme ve temsil özelliklerini yansıtan soruların yer aldığı fark edilmiştir. Ayrıca etkinlik türü faaliyette tüm standartlarda değerlendirilen en az bir etkinliğin olduğu görülmektedir.

Muhakeme-ispat özelliği ile 7. sinıf düzeyindeki cebirsel faaliyetlerde daha fazla karşılaşılmıştır. Problem ve örnek türü faaliyetlerde de bu standarda dair özellikler gözlenmiştir. Özellikle tüm etkinliklerin muhakeme-ispat türünde görevler içerdiği fark edilmiştir.7. sınıfa ait bir etkinlik faaliyeti şu şekildedir:

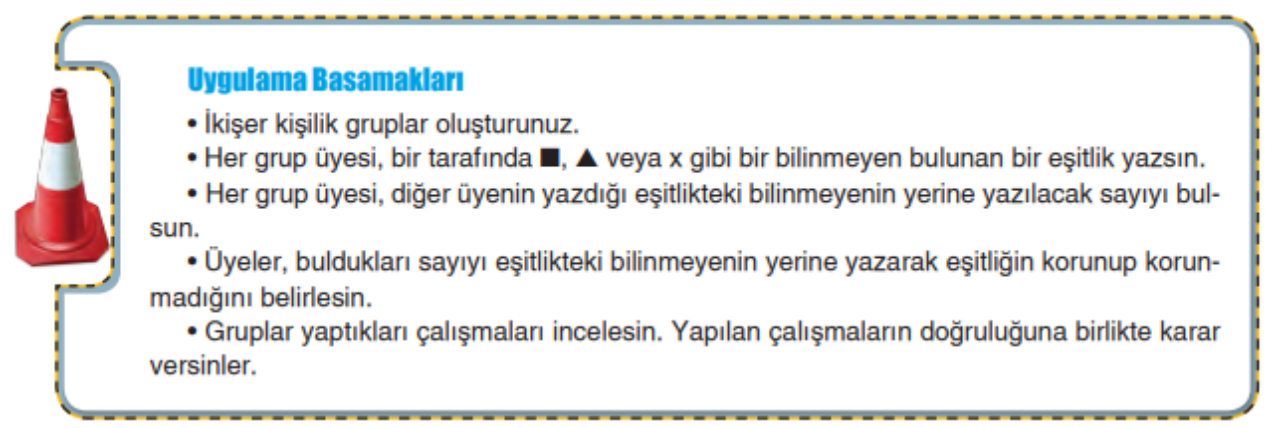

Şekil 5. 7. sınıfa ait bir etkinlik (Koza, 2018, s. 115)

Şekil 5'te yer alan etkinlikte son iki görev, eşitliğin să̆lanıp sağlanamayacă̆ının belirlenmesi ve sonucun doğruluğuna tartışarak karar verilmesi muhakeme-ispat özelliği gösteren görevlerdir. Diğer etkinliklerin de bu şekilde öğrencileri cevabın doğruluğundan emin olma ve karar verme becerilerini ön plana çıkarmaya yarayan görevler içerdiği tespit edilmiştir.

Temsil standardı özellikle kazanımın oluşturulması aşamasında yani etkinlik ve örnek faaliyetlerinde daha fazla dikkate alınırken, öğrencilerin bilgilerinin ölçüldüğü ve kendi öğrenmesi hakkında bilgi sahibi olduğu uygulama ve değerlendirme sorularında geri planda kaldığı fark edilmiştir. Benzer şekilde diğer standartlarda da uygulama ve değerlendirme sorularının standartları temsil etme özelliği bakımından etkinlik, örnek ve problem faaliyetlerine nazaran zayıf kaldığı söylenebilir.

\section{Sinıf Bulguları}


8. sınıfta cebir öğrenme alanı ile ilgili 5 etkinlik, 1 hazırlık çalışması, 111 örnek, 3 problem, 65 uygulama sorusu ve 82 tane değerlendirme sorusu olmak üzere toplam 267 faaliyet incelenmiştir (bkz. Ek 1). Bu faaliyetlere ait analizler Tablo 6'da verilmiştir.

Tablo 6. 8. sinıfa ait veri analizleri

\begin{tabular}{|c|c|c|c|c|c|c|}
\hline Faaliyet & $\begin{array}{l}\text { Problem } \\
\text { Çözme }\end{array}$ & $\begin{array}{l}\text { Problem } \\
\text { Kurma }\end{array}$ & $\begin{array}{l}\text { Muhakeme- } \\
\text { İspat }\end{array}$ & İletişim & İlişkilendirme & Temsil \\
\hline Hazırlık Sorusu & - & - & - & 1 & - & - \\
\hline Etkinlik & - & - & 1 & 4 & 4 & - \\
\hline Örnek & 7 & - & 1 & 62 & 49 & 31 \\
\hline Problem & 3 & - & - & 3 & 3 & - \\
\hline Uygulama Soruları & 12 & - & - & 23 & 25 & 4 \\
\hline $\begin{array}{l}\text { Değerlendirme } \\
\text { Soruları }\end{array}$ & 20 & - & - & 33 & 30 & 5 \\
\hline Toplam & $42(\% 15.73)^{*}$ & - & $2(\% 0.74)$ & $126(\% 47.19)$ & $111(\% 41.57)$ & $40(\% 14.98)$ \\
\hline
\end{tabular}

*267 faaliyet içindeki oranı temsil etmektedir.

Tablo 6 incelendiğinde, 8. sınıf cebirsel faaliyetlerde problem kurma standardının hiç yer almadığı ve muhakeme-ispat standardının ise sadece 2 faaliyette yer aldığ görülmektedir. Muhakeme-ispat türünde olan faaliyetlerin, sonucun doğruluğunun gösterilmesi ve elde edilen de ğerin denklemi să̆layıp sağlamadiğ sınıf düzeylerinde olduğu gibi 8. sınıfta da ön planda yer almıştır. Özellikle konu anlatımını açıklayıcı kılan örnek türü faaliyetlerde iletişim, ilişkilendirme ve temsil özelliği fazlaca yer almıştır. Diğer sınıf düzeylerinden farklı olarak faaliyetlerin ilişkilendirme özelliğine, bu sınıf düzeyinde \%41.57 oranıyla daha sık yer verildiği fark edilmiştir. Örnek durum Şekil 6'da verilmiştir.

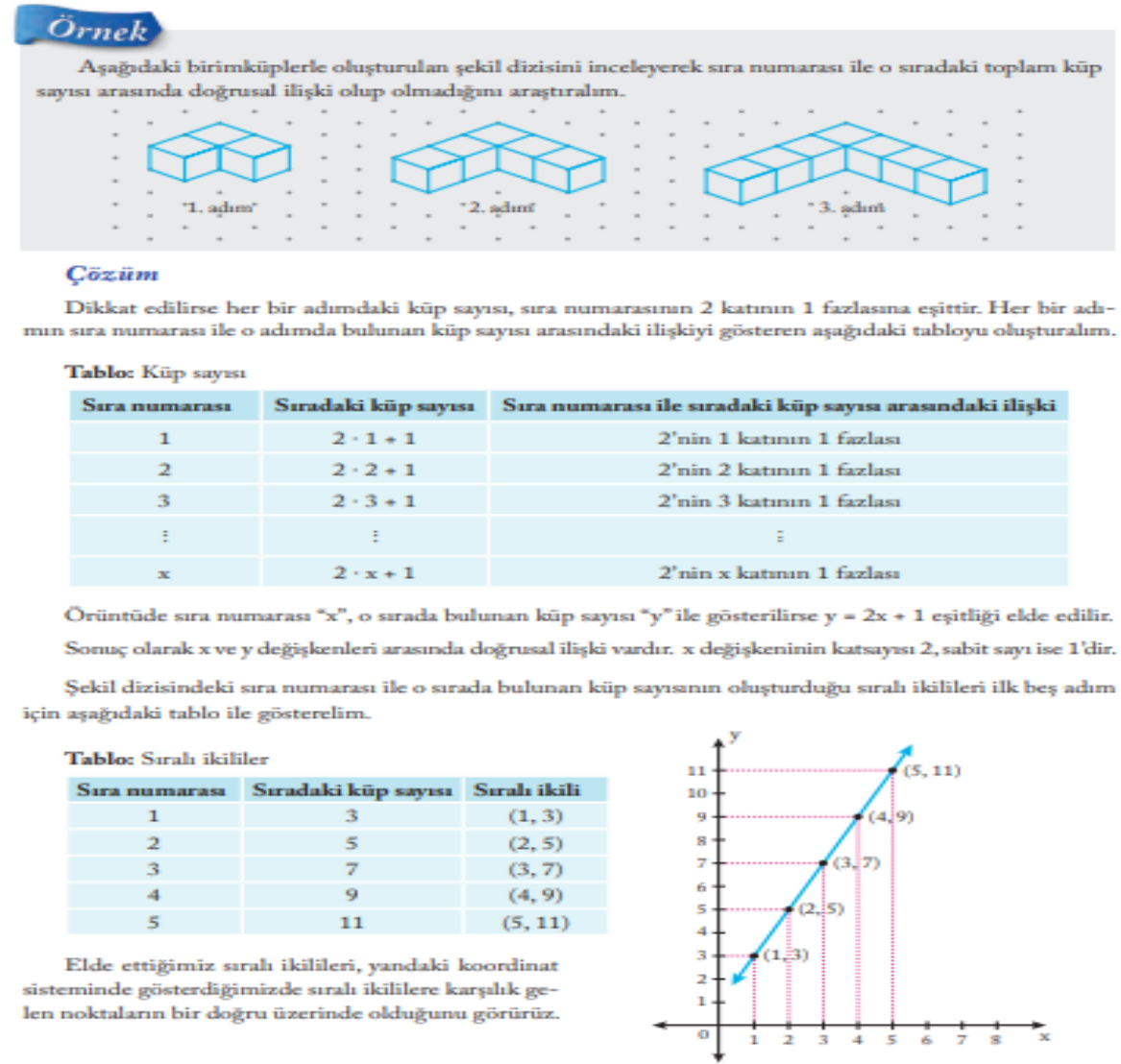


Şekil 6. 8. Sınıfa ait bir örnek (Ekoyay, 2018, s. 149)

Şekil 6'da yer alan etkinlikte öğrencilerden, şekil dizisini inceleyerek sıra numarası ile o sıradaki toplam küp sayısı arasında bir örüntü bulmaları ve bu örüntünün doğrusal olup olmadığını incelemeleri istenmektedir. Çözüm kısmında yapılan yönlendirmeler; verilerin düzenlenmesi için bir tablonun oluşturulması ve elde edilen ilişkinin doğrusallığının daha rahat gözlemlenmesi için grafik oluşturulması örnek durumun temsil özelliğinde olduğunu göstermektedir. Diğer yandan sıralı ikililerin oluşturulması, genel kuralın ifade edilmesi ve örnekte yer alan şeklin tabloda sözel ifadelerle açıklanması örnek durumun iletişim özelliğinde olduğunu işaret etmektedir. 8. sınıfta ilişkilendirme standardı özelliğinde olan faaliyetler genel olarak bu şekildedir.

Tablo 6'ya göre konu anlatımı sırasındaki faaliyetlerden ziyade bölüm sonu değerlendirme faaliyetlerinde standartların daha yoğun kullanıldığı ifade edilebilir. Örneğin, problem çözme faaliyeti uygulama ve değerlendirme sorularında daha fazla yer almaktadır. Benzer durumu iletişim ve ilişsilendirme için de söylemek mümkündür. Fakat temsil standardı için tam tersi bir durum gözlenmektedir. Örneklerde sıklıkla kullanılan temsil özelliğine uygulama ve değerlendirme sorularında pek rastlanmamaktadır.

\section{Tartışma ve Sonuç}

$\mathrm{Bu}$ çalışmada ortaokul matematik ders kitaplarında yer alan cebirsel faaliyetler matematiksel süreç standartlarına göre incelenmiştir. Elde edilen bulgulara göre, 396 faaliyetin \%19.19'u problem çözme, \%0.50'si problem kurma, \%6.81'i muhakeme-ispat, \%49.74'ü iletişim, \%32.57'si ilişkilendirme ve \%16.91'i temsil özelliğindedir (bkz. Tablo 3). Her sınıf düzeyinde ise ihtiva ettikleri faaliyet sayısına göre bu oranlar farklılaşmaktadır. 5. sınıfta cebir öğrenme alanına ait kazanım yer almadığı için herhangi bir veri elde edilememiştir. Diğer sınıf düzeylerinde faaliyetlerin en fazla iletişim özelliğinde olduğu tespit edilmiştir. 6. ve 8. sınıf için faaliyetlerin problem kurma ve muhakeme-ispat özellikleri de diğerlerine nazaran daha geri planda kalmıştır. 7. sınıf cebirsel faaliyetlerinin diğer iki sınıf düzeyine göre matematiksel süreç standartlarını ihtiva etme bakımından daha iyi düzeyde olduğu söylenebilir. Bu sınıf düzeyinde faaliyetlerin diğer sınıf düzeylerinden farklı olarak problem çözme, muhakeme-ispat ve temsil özelliğinde daha fazla yer aldığı fark edilmiştir. Özellikle etkinlik ve problem türü faaliyetlerin en az üç süreç standardı özelliği taşıdığ 1 görülmüştür. MEB (2018) cebir öğrenme alanının uygulanması için matematiksel anlamın geliştirilmesine öncülük eden becerilerin dikkate alınmasını önermektedir. Nitekim Trybulski’ye (2007) göre cebir matematiksel düşünmenin gelişimine destek sağlayan bir düşünme tarzına sahiptir ve matematiksel süreç becerilerin hepsini içerir.

$\mathrm{Bu}$ çalışmada cebirsel faaliyetlerde 6 . sınıfta sadece 1 durum problem çözme olarak değerlendirilmiştir. $\mathrm{Bu}$ ise problem çözmenin cebirsel faaliyetlerde neredeyse hiç olmadığını göstermektedir. 7. sınıfta problem çözme faaliyetleri $\% 31.73$ oranla diğer iki sınıf düzeyine göre daha iyi durumdadır. Fakat detaylı şekilde incelendiğinde, problem çözme özelliğinde faaliyetlerin daha çok konu anlatımı esnasındaki faaliyetlerde kullanıldı̆̆ı, uygulama ve değerlendirme sorularında daha az yer aldığı görülmüştür. 8.sınıfta tam tersi bir durum söz konusudur. $\mathrm{Bu}$ sınıf düzeyinde problem çözme faaliyetleri daha çok uygulama ve 
değerlendirme sorularında yer almaktadır. Problem çözme, alan uzmanlarının ve müfredat geliştirme uzmanının ders kitapları aracılığıyla öğretmenin zor olduğunu kabul ettiği bir konudur ve bu durum bilgisayar çağının imkânlarını kullanmak için iyi bir firsattır (Marshall, 1996). Fakat ders kitaplarında problem çözme ile ilgili hem yeteri kadar cebirsel faaliyetle karşılaşılmamış hem de teknolojinin entegre edildiği herhangi bir faaliyet tespit edilmemiştir. Oysa problem çözme hem matematik öğretiminde hem de matematik öğreniminde temel amaç olarak görülmektir (Wilson vd., 1993). Miller ve Nunn'e (2001) göre birey çocukluğundan itibaren problem çözme davranışı gösterir ve bu davranış gelişim gösterdiği dönem okul yıllarına denk gelir. Dolayısıyla ders kitaplarında yer alan etkinliklerin problem çözme özelliğinde olması gereklidir.

Araştırma verilerinde problem kurma özelliğinde olan toplamda iki faaliyetle karşılaşılmıştır. Bu sayı toplam faaliyet içerisinden \%1'den daha küçük bir orana denk gelmektedir. 8. sınıfta ise problem kurma faaliyetlerine cebir öğrenme alanında hiç yer verilmediği görülmektedir. Aslında diğer sınıf düzeylerinde de birer tane olması dikkate alındığında, ortaokul cebirsel etkinliklerde problem kurma özelliğine neredeyse hiç yer verilmediği söylenebilir. Ellerton ve Clarkson (1996)'a göre problem kurma, matematiğin iki temeli olan problem çözme ve problem kurmanın bir ayağıdır. Üstelik matematikte ilerlemek ve gelişmek için yaratıcılığ savunan yapılandırmacılık felsefesinin bu amacını gerçekleştirmenin bir yolu problem kurma becerisinin gelişimi ile ilgilidir (Christou vd., 2005). Çimen ve Y1ldız (2017) matematik ders kitaplarında problem kurma etkinliklerine ne derece yer verildiğini araştırdıkları çalışmalarında, bu tür etkinliklerin alt öğrenme alanlarına dengeli bir şekilde dağılmadığı, sayısının sınırlı kaldığı bulunmuştur.

Cebirsel faaliyetler incelendiğinde toplamda 396 faaliyetin 27'sinin (\%6.81) muhakeme-ispat özelliğinde olduğu bulunmuştur. $\mathrm{Bu}$ faaliyetlerin sonucun doğruluğundan emin olmak için kontrol yapılması ve sağlama yapma özelliğinde olduğu tespit edilmiştir. 7. sınıf faaliyetlerinin \%23.07 oranla diğer sınıf düzeylerine göre muhakeme-ispat özelliği açısından daha zengin olduğu görülmektedir. Ayrıca muhakeme-ispat türü faaliyetlerin daha çok konu anlatımı esnasındaki faaliyetlerde yer aldığı bulunmuştur. Hanna ve Barbeau'e (2008) göre matematiksel ispat matematiksel bilgilerin ilişkilendirilmesine dayanan ve matematiğin gelişimine katkı sunan bir araçtır. Benzer şekilde Knuth (2002) ispatın matematiksel anlamayı destekleyerek öğrenci öğrenmesine yardımcı olan bir kavram olduğunu ifade etmektedir. Fakat ders kitaplarında yer alan faaliyetlerin, ispatın önemini yeteri kadar yansıtamadığı söylenebilir. Nitekim Zeybek vd. (2018) yaptıkları çalışmada ortaokul ders kitaplarının matematiksel etkinliklerinin hepsini incelemiş ve elde ettikleri bulgular ile ders kitaplarında yer alan muhakeme-ve-ispat etkinliklerinin sayısının güncel eğitim reformlarının ve matematik eğitimcilerinin önerileri ile uyuşmadığını ileri sürmüşlerdir. Buna karşılık öğrencilerin ispat yapabilme özelliklerinin zayıf olduğunu ortaya koyan çalışmalar da vardır (bkz. Knuth, Choppin, ve Bieda, 2009). Harel ve Sowder'e (2007) göre ortaokul öğrencilerinin ispat yapabilme özellikleri zayıftır ve bu durumun nedenlerinden biri de ders kitaplarıdır. Benzer şekilde Erdem ve Gürbüz (2015) de 7. sınıf öğrencilerinin ispat yapabilme özelliklerinin orta ve düşük düzeyde olduğu ve matematiksel ispat yeteneğinin gelişimi için ispat özelliğinde problemlerle uğraşmaları gerektiğini ifade etmektedirler. Öğrencilerin ispat yeteneklerinin 
gelişmesi için ders materyallerinin ispat özelliğinin tekrardan gözden geçirilmesinin gerekli olduğu düşünülmektedir.

İletişim özelliği tüm cebirsel faaliyetlerde \% 49.74'le en sık karş1laşılan süreç standardı olmuştur. Sınıf bazında değerlendirilecek olursa, iletişim özelliği 6. sınıfta \%56, 7. sınıfta $\% 54.80$ ve 8 . sınıfta \%47.19 oranla temsil edilmiştir. Her sınıf düzeyi için faaliyetlerde nerdeyse yarı yarıya yer aldığı söylenebilir. Ayrıca bu standardın hem konu anlatımı hem de konu sonu uygulama ve değerlendirme türü faaliyetlerde benzer oranlarda yer aldığ bulunmuştur. Ferrari (2004) iletişim ile düşünce gelişimi arasında ilişkinin tartışmalı bir konu olduğunu, fakat sözel dilin matematiksel aktivitelerde yaygın bir şekilde kullanıldığını ifade etmektedir.

Matematik günlük yaşamda karşılaşılan problemleri çözme çabasında önemli rol oynar ve bu özelliği ilişkilendirme becerisinin ortaya çıkmasına öncülük eder (Yulianto vd., 2019). İlişkilendirme matematiksel kavramlarla günlük yaşam arasında yapılabildiği gibi matematiğin diğer kavramları arasında da yapılabilir (Putri ve Santosa, 2015). Bu becerinin aktif hale getirilmesi, sayılan özelliklerinin öğrenci ile karşılaştırılması gereklidir. Bu ise öğretim yöntemi ya da öğretim materyalleri ile mümkün olabilir. Bu çalışma bulguları ilişkilendirme özelliğinin 396 faaliyette $\% 32.57$ oranla yer aldığını göstermektedir. 6 . ve 7 . sınıf cebirsel faaliyetlerinden ziyade 8 . sınıfta daha fazla sayıda ilişkilendirme özelliğine sahip cebirsel faaliyetler tespit edilmiştir. Cebir öğrenme alanı işlenirken gerekli görülen yerlerde diğer öğrenme alanlarındaki kazanımlarla ilişkilendirilmesinin gerekli olduğu özellikle belirtilmiştir (MEB, 2018). Bu araştırmanın bulguları, ilişkilendirmenin formel yollarla faaliyetler aracılığıyla yapılmadığını ortaya koymaktadir.

Abrams’a (2007) göre öğrenciler en iyi modelleme sürecinin anlaşılması bağlamında uzmanlaşır. O yüzden öğrencilerin temsilleri oluşturma alışkanlıkları geliştirilmelidir. Bu çalışmada ortaokul cebirsel faaliyetler içinden 67'sinin (\%16.91) temsil özelliğinde olduğu görülmüştür. Temsil özelliğindeki faaliyet sayısı yıla göre artış göstermiştir. Temsil özelliğindeki faaliyetler 6. sınıfta yok denecek kadar az bulunmuştur. 7. sınıfta konu anlatımı sırasında ve sonrasında faaliyet sayısı bakımından orantılı şekilde bir dağılım gözlenirken, 8 . sınıfta daha çok konu anlatımı sırasındaki faaliyetlerde bu özelliğin olduğu tespit edilmiştir. Matematiksel temsil ile ilgili yapılan çalışmaların genellikle öğretmen ve öğrencinin temsil yeteneğinin sorgulandığı ya da değişiminin izlendiği çalışmalara rastlanmaktadır (Cuoco, 2001; Goldin, 2003; Wu, 2004). Goldin (2003) cebirsel bir ifadenin grafikle temsil edilebileceği gibi grafiğin de cebirsel bir ifadeye dönüştürülebileceğinin matematiksel bir zenginlik olduğunu vurgulamaktadır. Wu (2004) ise bu durumun öğrenen ve öğretenin yorumlama gücüyle alakalı olduğunu ifade etmektedir. Yorumlama yeteneğinin gelişiminin bir yolu bu tarz faaliyetlerle sürekli olarak karşılaşmakla mümkündür. Yani temel ders materyali özelliğinde olan ders kitaplarının içeriklerinin temsil özelliği gözetilerek yapılandırılması yorumlama becerisinin gelişimine olumu anlamda katkılar sunabilir.

\section{Sonuç ve Öneriler}


$\mathrm{Bu}$ araştırmada elde edilen veri analizleri sonucunda dört sonuca ulaşılmıştır. Bunların ilki, ortaokul ders kitaplarında yer alan cebirsel faaliyetlerin problem çözme, problem kurma, muhakeme-ispat ve temsil standartları bakımından yetersiz olduğudur. Nitekim matematik müfredatında (MEB, 2018) cebirsel düşünme perspektifinden, matematiksel becerilerle ilgili önerilen durumlarla ders kitaplarının uyuşmadığı görülmüştür. İkinci sonuç, sınıf düzeylerinin matematiksel süreç standartlarını yansıtan faaliyetleri bakımından farklılaşmasıdır. 7. sınıfın cebirsel faaliyetlerinin diğer iki sınıf düzeyindeki faaliyetlerden matematiksel süreç standartları bakımından daha zengin olduğu görülmüştür. Üçüncü sonuç faaliyetlerin süreç standartları bakımından farklılaşmasıdır. $\mathrm{Bu}$ sonuca göre etkinlik ve problem türü faaliyetlerin süreç standartlarını ihtiva etme durumuna göre diğer faaliyet türlerine göre daha zengin içerikte oldukları fark edilmiştir. Araştırmada son olarak, konu anlatımı sırasında yer alan faaliyetler ile öğrencilerin bilgilerinin ölçüldüğü uygulama ve değerlendirme faaliyetlerinin süreç standartlarını ihtiva etme açısından uyuşmadığı bulunmuştur.

$\mathrm{Bu}$ araştırmada ders kitaplarının cebir öğrenme alanında yer alan faaliyetlerin tamamı matematiksel süreç standartları çerçevesinde incelenmiştir. Yapılan inceleme sonucunda cebirsel faaliyetlerin iletişim ve ilişkilendirme özelliği hariç diğer süreç standartlarını temsil etme konusunda yetersiz olduğu ortaya koyulmuştur. Cebir, bireyin erken çocukluktan itibaren gördüğü ve öğretim hayatı boyunca karşılaştığı bir öğrenme alanıdır (Bush ve Karp, 2013). Ayrıca matematiğin diğer öğrenme alanları ile yakından ilişkilidir. Üstelik problem çözme, problem kurma, muhakeme-ispat ve temsil özelliği matematiksel düşünmenin gelişiminde ve matematiksel anlamın oluşturulmasında oldukça önemli bir yere sahiptir. Dolayısıyla cebirsel faaliyetlerde matematiksel süreç standartlarının sistemli bir şekilde ve yeterli düzeyde yer alması öğretimin geliştirilmesi için gerekli görülmekte ve önerilmektedir.

$\mathrm{Bu}$ araştırmada özel olarak cebir öğrenme alanında yer alan faaliyetlerin analizi yapılmıştır. Diğer öğrenme alanlarında yer alan faaliyetlerin de matematiksel süreç standartları tarafından analiz edilmesi, kitap güncelleme çalışmalarına bir fikir sağlayabilir. Problem çözme, muhakeme-ispat gibi matematiksel becerilerin gelişiminin erken yaşlarda olduğu düşünüldüğünde benzer çalışmaların ilkokul matematik ders kitaplarındaki faaliyetlerle yapılması önerilmektedir.

\section{Makalenin Bilimdeki Konumu}

\section{Matematik ve Fen Bilimleri Eğitimi Bölümü/Matematik Eğitimi}

\section{Makalenin Bilimdeki Özgünlüğü}

Literatürde her bir süreç standardına ait detaylı çalışmalara, hatta ders kitabı inceleme çalışmalarına da rastlanmaktadır. Bu çalışmada ise tüm süreç standartları bir arada incelenerek daha kapsamlı bir yapı sunulmaya çalışılmıştır. Dolayısıyla bu çalışma ile daha fazla okuyucuya ulaşılacağı düşünülmektedir. Üstelik ortaokul matematiğin araştırmacıların çalışmayı sıklıkla tercih ettikleri cebir öğrenme alanında yer alan faaliyetlerin analiz edilmesi de bu sanıyı desteklemektedir. Diğer yandan literatürden farklı olarak problem kurma becerisinin de bir süreç standardı olarak ayrıca ele alınmıştır. Böylelikle öğrencilerin matematiksel anlamalarının gelişimi için bir araç olarak görülen problem kurmanın önemi üzerinde durulmuştur. 


\section{Kaynaklar}

Abrams, J. P. (2001). Teaching mathematical modeling and the skills of representation. (Ed. Albert A. Cuoco). İçinde The roles of representation in school mathematics, 269-282.

Almeida, D. (2000). A survey of mathematics undergraduates' interaction with proof: some implications for mathematics education. International Journal of Mathematical Education in Science and Technology, 31(6), 869-890.

Brendefur, J., \& Frykholm, J. (2000). Promoting mathematical communication in the classroom: Two preservice teachers' conceptions and practices. Journal of Mathematics Teacher Education, 3(2), 125-153.

Bush, S. B., \& Karp, K. S. (2013). Prerequisite algebra skills and associated misconceptions of middle grade students: A review. The Journal of Mathematical Behavior, 32(3), 613632.

Christou, C., Mousoulides, N., Pittalis, M., Pitta-Pantazi, D., \& Sriraman, B. (2005). An empirical taxonomy of problem posing processes. ZDM, 37(3), 149-158.

Cooke, B. D., \& Buchholz, D. (2005). Mathematical communication in the classroom: A teacher makes a difference. Early Childhood Education Journal, 32(6), 365-369.

Cuoco, A. A. (2001). Preface. In A. A. Cuoco \& F. R. Curcio (Eds.) The role of representation in school mathematics (70-72). Reston, VA: NCTM.

Çimen, E. E., \& Yıldız, Ş. (2017). Ortaokul matematik ders kitaplarında yer verilen problem kurma etkinliklerinin incelenmesi. Turkish Journal of Computer and Mathematics Education, 8(3), 378-407.

Dursun, Ş., \& Dede, Y. (2004). Öğrencilerin matematikte başarısını etkileyen faktörler matematik öğretmenlerinin görüşleri bakımından. Gazi Üniversitesi Gazi Ĕ̌itim Fakültesi Dergisi, 24(2), 217-230.

Ellerton, N. F., \& Clarkson, P. C. (1996). Language factors in mathematics teaching and learning. (Ed. Alan J. Bishop, Ken Clements, Christine Keitel, Jeremy Kilpatrick, Colette Laborde). İçinde International handbook of mathematics education (987-1033). Springer, Dordrecht.

Erdem, E., \& Gürbüz, R. (2015). An Analysis of Seventh-Grade Students' Mathematical Reasoning. Cukurova University Faculty of Education Journal, 44(1), 123-142.

Ferrari, L., P. (2004). Matematical language and advanced mathematics learning. Proceedings of the 28th Conference of the International Group for the Psychology of Mathematics Education, 2, 383-390.

Goldin, G. A. (2003). Representation in school mathematics: a unifying research perspective. In J. Kilpatrick, W. G. Martin \& D. Schifter (Eds.), A research companion to Principles and Standards for School Mathematics (pp. 275-285). Reston, NJ: NCTM.

Hanna, G., \& Barbeau, E. (2008). Proofs as bearers of mathematical knowledge. ZDM, 40(3), 345-353.

Hare, A. Y. M. (1999). Revealing what urban early childhood teachers think about mathematics and how they teach it: Implications for practice (Yayınlanmamış doktora tezi). University of North Texas. 
Harel, G., \& Sowder, L. (2007). Toward comprehensive perspectives on the learning and teaching of proof. Second handbook of research on mathematics teaching and learning, 2, 805-842.

Işık, A., \& Konyalığlu, A. C. (2005). Matematik eğitiminde görselleştirme yaklaşımı. Atatürk Üniversitesi Kazım Karabekir Eğitim Fakültesi Dergisi, 11, 462-471.

Johansson, M. (2003). Textbooks in mathematics education: a study of textbooks as the potentially implemented curriculum (Yayınlanmamış yüksel lisans tezi). Luleå: Department of Mathematics, Luleå University of Technology.

Kennedy, L., Tipps, S., \& Johnson, A. (2007). Guiding children's learning of mathematics. Cengage

Learning. https://books.google.com.tr/books?hl=tr\&lr=\&id=mrFYTHOjHjYC\&oi=fnd\&pg=PR7 \&dq=Kennedy,+Tipps+ve+Johnson,+2004\&ots=OIh0UOJGKF\&sig=UNMpnYzGF1 UcOssM1bTs6746B2M\&redir_esc=y\#v=onepage \&q=Kennedy\%2C\%20Tipps\%20ve \%20Johnson\%2C\%202004\&f=false adresinden 08.05.2020 tarihinde alınmıştır.

Knuth, E. J. (2002). Proof as a tool for learning mathematics. Mathematics Teacher, 95(7), 486490.

Knuth, E., Choppin, J., \& Bieda, K. (2009). Middle school students' production of mathematical justifications. http://hdl.handle.net/1802/27754 adresinden 18.03.2020 tarihinde alınmıştır.

Marshall, G. (1996). Problem solving about problem solving: Framing a research agenda. https://files.eric.ed.gov/fulltext/ED398890.pdf adresinden 15.04.2020 tarihinde alınmıştır.

McMillan, J.H., \& Schumacher, S. (2010). Research in education: Evidence based inquiry (7th Edition). London: Pearson.

Miles, M. B., \& Huberman, A. M. (1994). Qualitative data analysis (2 ${ }^{\text {nd }}$ ed), CA: Sage Publications.

Miller, M., \& Nunn, G. D. (2001). Using group discussion to improve social problem solving and learning. Education, 121(3), 470-475.

Milli Eğitim Bakanlığı [MEB]. (2018). İlköğretim Matematik 5 Ders Kitabı. Ankara: SDR Dikey Yayıncılık.

Milli Eğitim Bakanlığı [MEB]. (2018). İlköğretim Matematik 6 Ders Kitabı. Ankara: Berkay Yayıncilık.

Milli Eğitim Bakanlığı [MEB]. (2018). İlköğretim Matematik 7 Ders Kitabı. Ankara: Koza Yayınc1lık.

Milli Eğitim Bakanlığı [MEB]. (2018). Illköğretim Matematik 8 Ders Kitabı. Ankara: Ekoyay Eğitim Yayıncılık.

Milli Eğitim Bakanlığı, Talim ve Terbiye Kurulu Başkanlığı (2018). Ilkokul ve ortaokul matematik dersi ögretim programı. Ankara: MEB.

National Council of Teachers of Mathematics [NCTM]. (2020). Principles and standards for school mathematics. NCTM, Reston, VA (2000). https://www.nctm.org/uploadedFiles/Standards_and_Positions/PSSM_ExecutiveSum mary.pdf adresinden 23.06.2020 tarihinde alınmıştır. 
Olkun, S., \& Toluk Uçar, Z (2012). İlköğretimde etkinlik temelli matematik öğretimi (5. Bask1), Ankara: Eğiten Kitap.

Papanastasiou, C. (2002). Effects of background and school factors on the mathematics achievement. Educational Research and Evaluation, 8(1), 55-70.

Pape, S. J., \& Tchoshanov, M. A. (2001). The role of representation(s) in developing mathematical understanding. Theory into Practice, 40(2), 118-127.

Polya, G. (2004). How to solve it: A new aspect of mathematical method (Vol. 85). Princeton university press. https://books.google.com.tr/books?hl=tr\&lr=\&id=z_hsbu9kyQQC\&oi=fnd\&pg=PP2\& dq $=+$ Polya, + G. + How+To+Solve+It:+A+New+Aspect+of+Mathematical+Method.+Pr inceton,+New+Jersey:+Princeton+University+Press,+1973\&ots=oYrJTnkQQ2\&sig=7 A234iMBLG3cFmaPU2qXc5MqEGU\&redir_esc =y\#v=onepage\&q\&f=false adresinden 08.02.2020 tarihinde alınmıştır.

Putri, R. I., \& Santosa, R. H. (2015). Keefektifan strategi REACT ditinjau dari prestasi belajar, kemampuan penyelesaian masalah, koneksi matematis, self-efficacy. Jurnal Riset Pendidikan Matematika, 2(2), 262-272.

Ramirez, G., Chang, H., Maloney, E. A., Levine, S. C., \& Beilock, S. L. (2016). On the relationship between math anxiety and math achievement in early elementary school: The role of problem solving strategies. Journal of Experimental Child Psychology, 141, 83-100.

Silver, E. A. (1994). On mathematical problem posing. For the Learning of Mathematics, 14(1), 19-28.

Smith III, J. P., Males, L. M., Dietiker, L. C., Lee, K., \& Mosier, A. (2013). Curricular treatments of length measurement in the United States: Do they address known learning challenges?. Cognition and Instruction, 31(4), 388-433.

Stein, M. K., \& Lane, S. (1996). Instructional tasks and the development of student capacity to think and reason: An analysis of the relationship between teaching and learning in a reform mathematics project. Educational Research and Evaluation, 2(1), 50-80.

Stylianides, G. (2008). Analytic framework of reasoning-and-proving. For the Learning of Mathematics, 28, 9-16.

Stylianides, A. J. (2007). The notion of proof in the context of elementary school mathematics. Educational Studies in Mathematics, 65, 1-20.

Sukmaningthias, N., \& Hadi, A. R. (2016). Improve Analytical Thinking Skill and Mathematical Representation of The Students Through Math Problem Solving. In Proceeding of 3rd international conference on research, implementation and education of mathematics and science (pp. 449-454).

Trybulski, D. J. (2007). Algebraic reasoning in middle school classrooms: A case study of standards-based reform and teacher inquiry in mathematics (Yayınlanmamış doktora tezi). University of Pennsylvania.

Türkiye Yeterlilikler Çerçevesi [TYÇ]. 2015. Türkiye Yeterlilikler Çerçevesi. https://www.myk.gov.tr/images/articles/editor/130116/TYC_teblig_2.pdf adresinden 12.06.2020 tarihinde alınmıştır. 
Uğurel, I., \& Moralı, S. (2010). Matematik eğitimi ve dilbilim etkileşimine dayalı bir araştırma ve metodoloji alanı: Söylem çözümleme. NWSA, 5(1), 173-184.

Wilson, J. W., Fernandez, M. L., \& Hadaway, N. (1993). Mathematical problem solving. In Research Ideas for the Classroom: High School Mathematics, 57, 78. https://staff.tarleton.edu/brawner/coursefiles/507/Problem\%20solving\%20article\%20b y\%20Wilson.pdf adresinden 11.05.2020 tarihinde alınmıştır.

$\mathrm{Wu}, \mathrm{Z}$. (2004). The study of middle school teachers' understanding and use of mathematical representation in relation to teachers' zone of proximal development in teaching fractions and algebraic functions (Yayınlanmamış doktora tezi). Department of Teaching, Learning and Culture. Texas A\&M University, College Station.

Yıldırım, A., \& Şimşek, H. (2011). Sosyal bilimlerde araştırma yöntemleri. Ankara: Seçkin Yayınları.

Yulianto, A. R., Rochmad, R., \& Dwidayati, N. K. (2019). The Effectiveness of Core Models with Scaffolding to Improve The Mathematical Connection Skill. Journal of Primary Education, 8(4), 1-7.

Zeybek, Z., Üstün, A., \& Birol, A. (2018). Matematiksel ispatların ortaokul matematik ders kitaplarındaki yeri. Illköğretim Online, 17(3), 1317-1335.

\section{Summary \\ Statement of Problem}

The main purpose of the education system is to raise individuals with knowledge, skills and behaviors integrated with our values (Ministry of National Education [MoNE], 2018). These concepts constitute general competencies and are acquired within the framework of the programs in our education system. The Turkish Qualifications Framework [TQF] (2018) is one of the core competencies identified mathematical competence. Mathematical competence is the development of the mathematical thinking so that the individual can solve the problems he/she encounters in his normal life. This concept is also related to the ability to use mathematical thinking and practice. The National Council of Teachers of Mathematics [NCTM] (2020) competence in mathematics is the key to a productive and bright future and consists of a number of skills. The Council expressed these skills as process standards that enable the student to know and do mathematics and gathered them under five headings: problem solving, reasoning and proof, communication, connection and representation.

In this study, it is aimed to examine the activities of algebra learning field in mathematics textbooks within the framework of mathematical process standards. The importance of this study can be expressed under three headings. The first is that all the mathematical process standards are included in this study. Thus, it is thought that this study will appeal to more readers. There are many studies in the literature that mention the positive effects of the skills contained in standards in the process of teaching and learning of mathematics (eg Ramirez, Chang, Maloney, Levine and Beilock, 2016; Stylianides, 2007). In addition, analyzing the study within the scope of all skills included in the mathematics curriculum is valuable. Such studies can provide mathematics educators with insight into the development process of textbooks and give them an idea of what to do or 
not to do. According to Johansson (2003), textbook review studies can support countries' educational reform efforts. Finally, in the study, algebra learning area was selected specifically. While Trybulski (2007) states that algebraic thinking is the determinant of algebra, it is not only about algebra studies, but also includes process skills used by mathematical thinking such as problem solving, reasoning, representation. Therefore, it is important to reveal the power of this learning area to represent mathematical skills. In the research, an answer was sought for the following problem situation:

- What is the state of mathematical process standards in the algebra learning field of secondary school mathematics textbooks?

\section{Method}

In this study, algebraic activities in secondary school mathematics textbooks are examined. In this respect, research is a kind of document analysis. Document analysis is a non-interactive qualitative data collection method that the participant and the researcher do not face (Mcmillan \& Schumacher, 2010, p. 360). A total of 396 activities belonging to the algebra learning field of the mathematics program (MoNE, 2018) constitute the working group of this research (see Annex 1).

The data of the research were analyzed using descriptive and content analysis methods. Descriptive analysis is summarizing and interpreting data according to pre-determined categories (Yıldırım \& Şimşek, 2011, p. 224), while content analysis is to search for themes and patterns from the data (Glesne, 2013, p. 259). The analysis of mathematical activities was made according to the analytical framework of the mathematical process standards. This analytical framework consists of keywords that define each mathematical process standard (see Table 1). The analyzes were coded separately by two different coders and the coefficient of coherence between the coders was $92 \%$.

\section{Findings}

In the textbooks, a total of 396 activities related to algebra learning area were determined. Among these activities, it was observed that the sample case was the most common in the textbooks $(n=151)$ and the least was the preparation question $(n=6)$. In addition, it has been determined that the number of activities $(n=11)$ in the field of learning algebra is less than the others (see Annex 1).

If evaluated in terms of mathematical process standards, $19.19 \%$ of 396 activities are problem solving, $0.50 \%$ problem posing, $6.81 \%$ reasoning-proof, $49.74 \%$ communication, $32.57 \%$ connection and $16.91 \%$ representation (Table 3 ). With these data, it can be stated that almost half of the algebra learning area activities are communication standard. When analyzed by class levels, it is seen that communication standard is more common in activities for each class level.

Finally, if we consider classes according to process standards, it is seen that problem solving, communication, connection and representation activities are higher in 8th grade, and reasoning-proof activities are relatively higher in 7th grade (Table 3). Problem posing activities were encountered only twice, among all the secondary school algebra activities, one of which is the preparation question (6th grade) and one is the activity (7th grade). It was noticed that reasoning-proof studies were mostly in activity type activities (see Table 5-6). 


\section{Discussion and Conclusion}

As a result of the data analysis obtained in this research, four conclusions were reached. First of all, it can be said that algebraic activities in secondary school textbooks are inadequate in terms of problem solving, problem-posing, reasoning-proof and representation standards. As a matter of fact, from the algebraic perspective of thinking in the mathematics curriculum (MEB, 2018), it was observed that the recommended situations related to mathematical skills and textbooks do not match. The second result is that class levels differ in their activities that reflect the standards of mathematical processes. Algebraic activities of the 7th grade were found to be richer in terms of mathematical process standards than the activities of the other two grades. The third result is the differentiation of activities in terms of process standards. According to this result, it was noticed that activity and problem type activities are richer than the other activity types according to the process standards. Finally, it was found that the activities included in the subject expression and the application and evaluation activities in which the students' knowledge was measured did not match the process standards. 
YYÜ Eğitim Fakültesi Dergisi (YYU Journal of Education Faculty), 2021; 18(1)137-161,http://efdergi.yyu.edu.tr.

Ek 1. Sınıf düzeyine göre cebir öğrenme alanına ait faaliyet sayısı

\begin{tabular}{|c|c|c|c|c|c|c|c|c|c|c|c|}
\hline $\begin{array}{l}\text { Sinıf } \\
\text { Düzeyi }\end{array}$ & $\begin{array}{l}\text { Alt Öğrenme } \\
\text { Alanı }\end{array}$ & Kazanım & Etkinlik & $\begin{array}{l}\text { Hazırlık } \\
\text { sorusu }\end{array}$ & Örnek & Problem & $\begin{array}{l}\text { Alıştırma } \\
\text { sorusu }\end{array}$ & $\begin{array}{l}\text { Uygulama } \\
\text { Sorusu }\end{array}$ & $\begin{array}{l}\text { Ölçme } \\
\text { Sorusu }\end{array}$ & $\begin{array}{l}\text { Değerlendirme } \\
\text { sorusu }\end{array}$ & Toplam \\
\hline 5. Sinıf & - & - & - & - & - & - & - & - & - & - & - \\
\hline \multirow[t]{3}{*}{ 6. Sinıf } & \multirow[t]{3}{*}{$\begin{array}{l}\text { Cebirsel } \\
\text { İfadeler }\end{array}$} & $\begin{array}{l}\text { M.6.2.1.1. Sözel olarak verilen bir } \\
\text { duruma uygun cebirsel ifade ve verilen } \\
\text { bir cebirsel ifadeye uygun sözel bir } \\
\text { durum yazar. }\end{array}$ & \multirow[t]{3}{*}{-} & \multirow[t]{3}{*}{5} & \multirow[t]{3}{*}{6} & \multirow[t]{3}{*}{-} & \multirow[t]{3}{*}{7} & \multirow[t]{3}{*}{-} & \multirow[t]{3}{*}{-} & \multirow[t]{3}{*}{7} & \multirow[t]{3}{*}{25} \\
\hline & & $\begin{array}{l}\text { M.6.2.1.2. Cebirsel ifadenin değerini } \\
\text { değişkenin alacağı farklı doğal sayı } \\
\text { değerleri için hesaplar. }\end{array}$ & & & & & & & & & \\
\hline & & $\begin{array}{l}\text { M.6.2.1.3. Basit cebirsel ifadelerin } \\
\text { anlamını açıklar. }\end{array}$ & & & & & & & & & \\
\hline \multirow[t]{7}{*}{ 7. Sinıf } & \multirow[t]{3}{*}{$\begin{array}{l}\text { Cebirsel } \\
\text { İfadeler }\end{array}$} & $\begin{array}{l}\text { M.7.2.1.1. Cebirsel ifadelerle toplama } \\
\text { ve çıkarma işlemleri yapar. }\end{array}$ & \multirow[t]{3}{*}{3} & \multirow[t]{3}{*}{-} & \multirow[t]{3}{*}{17} & \multirow[t]{3}{*}{-} & \multirow[t]{3}{*}{-} & \multirow[t]{3}{*}{13} & \multirow[t]{3}{*}{-} & \multirow[t]{3}{*}{8} & \multirow[t]{3}{*}{41} \\
\hline & & $\begin{array}{l}\text { M.7.2.1.2. Bir doğal sayı ile bir cebirsel } \\
\text { ifadeyi çarpar. }\end{array}$ & & & & & & & & & \\
\hline & & $\begin{array}{l}\text { M.7.2.1.3. Sayı örüntülerinin kuralını } \\
\text { harfle ifade eder, kuralı harfle ifade } \\
\text { edilen örüntünün istenilen terimini } \\
\text { bulur. }\end{array}$ & & & & & & & & & \\
\hline & \multirow[t]{4}{*}{$\begin{array}{l}\text { Eşitlik ve } \\
\text { Denklem }\end{array}$} & $\begin{array}{l}\text { M.7.2.2.1. Eşitliğin korunumu ilkesini } \\
\text { anlar. }\end{array}$ & \multirow[t]{4}{*}{3} & \multirow[t]{4}{*}{-} & \multirow[t]{4}{*}{17} & \multirow[t]{4}{*}{16} & \multirow[t]{4}{*}{-} & \multirow[t]{4}{*}{14} & \multirow[t]{4}{*}{-} & \multirow[t]{4}{*}{13} & \multirow[t]{4}{*}{63} \\
\hline & & $\begin{array}{l}\text { M.7.2.2.2. Birinci dereceden bir } \\
\text { bilinmeyenli denklemi tanır ve verilen } \\
\text { gerçek hayat durumlarına uygun birinci } \\
\text { dereceden bir bilinmeyenli denklem } \\
\text { kurar. }\end{array}$ & & & & & & & & & \\
\hline & & $\begin{array}{l}\text { M.7.2.2.3. Birinci dereceden bir } \\
\text { bilinmeyenli denklemleri çözer. }\end{array}$ & & & & & & & & & \\
\hline & & $\begin{array}{l}\text { M.7.2.2.4. Birinci dereceden bir } \\
\text { bilinmeyenli denklem kurmay1 } \\
\text { gerektiren problemleri çözer. }\end{array}$ & & & & & & & & & \\
\hline 8. Sinıf & & $\begin{array}{l}\text { M.8.2.1.1. Basit cebirsel ifadeleri anlar } \\
\text { ve farklı biçimlerde yazar. }\end{array}$ & - & - & 43 & - & - & - & 20 & 24 & 87 \\
\hline
\end{tabular}


YYÜ Eğitim Fakültesi Dergisi (YYU Journal of Education Faculty), 2021; 18(1)137-161, http://lefdergi.yyu.edu.tr,

doi:10.33711/yyuefd.859526

Araştırma Makalesi

ISSN: 1305-2020

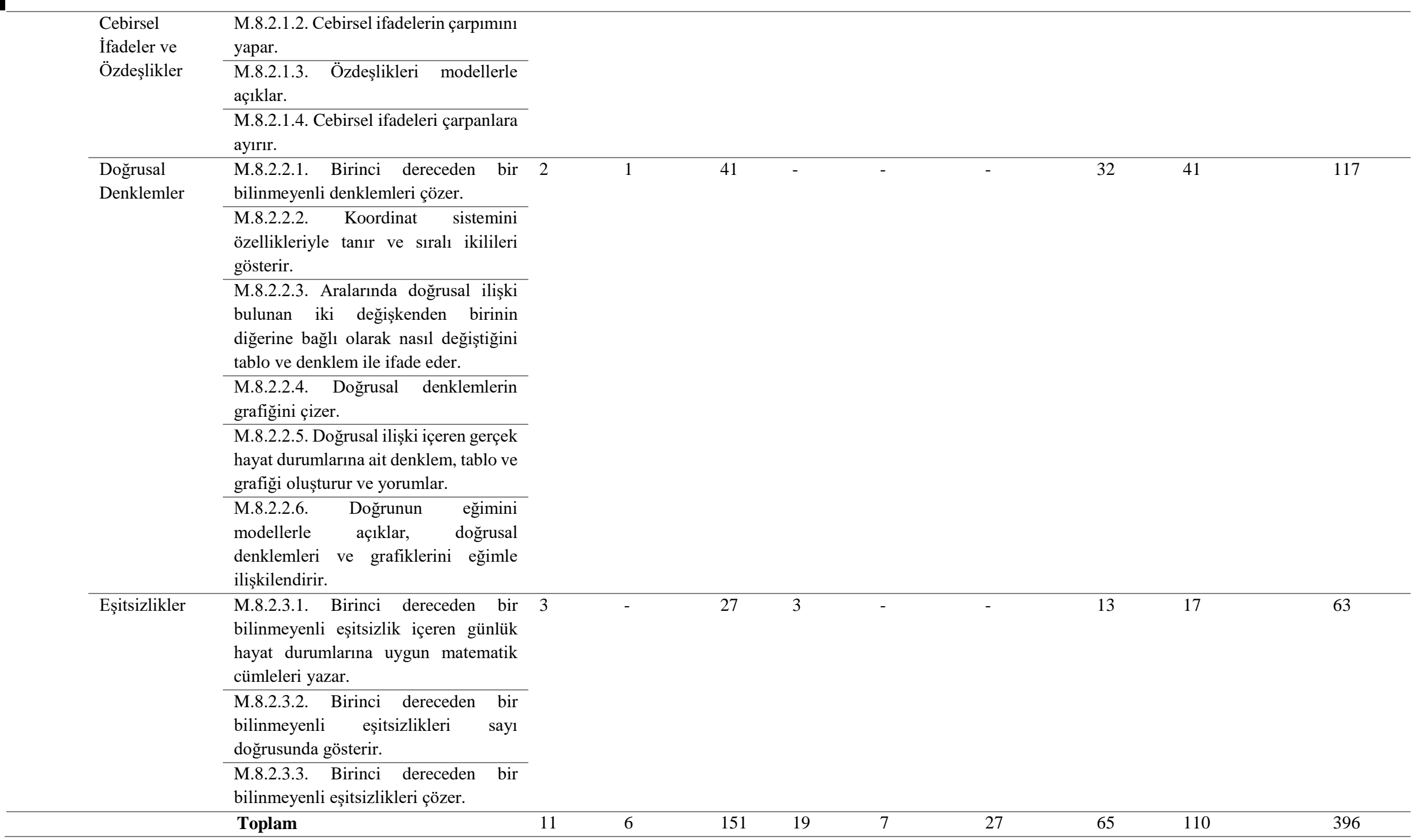

